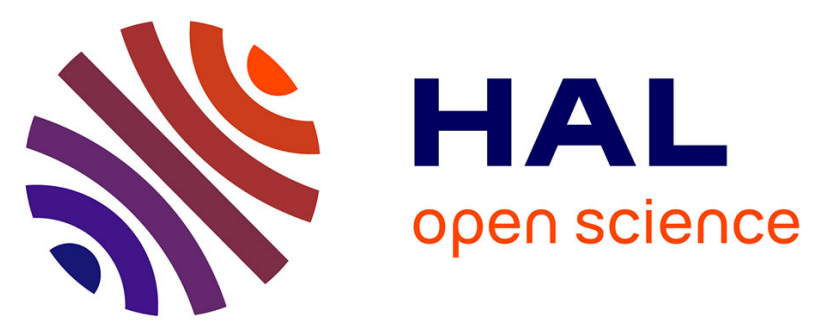

\title{
Chronological Constraints On Tsavorite Mineralizations and Related Metamorphic Episodes In Southeast Kenya
}

Jean-Emmanuel Martelat, Jean-Louis Paquette, Valérie Bosse, Gaston

Giuliani, Patrick Monie, Edward Omito, Cédric Simonet, Daniel

Ohnenstetter, Daniel Ichang'I, Christopher Nyamai, et al.

\section{To cite this version:}

Jean-Emmanuel Martelat, Jean-Louis Paquette, Valérie Bosse, Gaston Giuliani, Patrick Monie, et al.. Chronological Constraints On Tsavorite Mineralizations and Related Metamorphic Episodes In Southeast Kenya. The Canadian Mineralogist, 2017, 55 (5), pp.845-865. 10.3749/canmin.1700019 . hal-01616037

\section{HAL Id: hal-01616037 \\ https://hal.science/hal-01616037}

Submitted on 5 Dec 2017

HAL is a multi-disciplinary open access archive for the deposit and dissemination of scientific research documents, whether they are published or not. The documents may come from teaching and research institutions in France or abroad, or from public or private research centers.
L'archive ouverte pluridisciplinaire HAL, est destinée au dépôt et à la diffusion de documents scientifiques de niveau recherche, publiés ou non, émanant des établissements d'enseignement et de recherche français ou étrangers, des laboratoires publics ou privés. 


\title{
CHRONOLOGICAL CONSTRAINTS ON TSAVORITE MINERALIZATIONS AND RELATED METAMORPHIC EPISODES IN SOUTHEAST KENYA
}

\author{
JEAN-EMMANUEL MARTELAT \\ Laboratoire de Géologie de Lyon LGLTPE, Université de Lyon 1, ENSL, UMR 5276, 2 rue Raphaël Dubois, Géode, \\ 69622 Villeurbanne Cedex, France \\ Jean-Louis PAQUETTE and VaLerie BOSSE \\ Laboratoire Magmas et Volcans, Université Clermont Auvergne, CNRS, IRD, OPGC, 63000 Clermont-Ferrand, France

\section{GASTON GIULIANI} \\ Université Paul Sabatier, GET/IRD, UMR CNRS-IRD-CNES 5563, 14 avenue Edouard Belin, F-31400 Toulouse, France \\ Université de Lorraine, CRPG UMR 7358 CNRS-UL, 15 rue Notre-Dame-des-Pauvres, BP20, \\ 54501 Vandouvre-lès-Nancy Cedex, France \\ PATRICK MONIÉ
}

Géosciences Montpellier, Université Montpellier II, UMR 5243, 2 place Eugène Bataillon, 34095 Montpellier Cedex 05, France

EDWARD OMITO

Mines and Geology Department Taita-Taveta, P.O. Box 1043-80304, Wundanyi, Kenya

CÉDRIC SIMONET

Swensson \& Simonet Minerals, P.O. Box 2549200603 Lavington, Nairobi, Kenya

DANIEL OHNENSTETTER

4 rue Nicolas Chopin, 88130 Marainville-sur-Madon, France

Daniel ICHANG'I, Christopher NYAMAI, AND Abigail WAMUNYU

Department of Geology, University of Nairobi, Chiromo Campus, Riverside drive, P.O. Box 30197-00100 GPO, Nairobi, Kenya

\begin{abstract}
Tsavorite is exclusively hosted in the Neoproterozoic Metamorphic Mozambique Belt (NMMB). The gemstone mines, widespread between Kalalani (Tanzania) and Mgama Ridge (Kenya), define a continuous corridor over a hundred kilometers in length. The tsavorite is hosted by a metasedimentary sequence defined as the Kurase tsavorite-bearing metasediments (KuraseTB metasediments) that also hosts rubies. These metasediments underwent amphibolite-facies metamorphism and are surrounded by granulitic gneisses that are also of sedimentary origin (the Kurase high-temperature gneisses). All these rocks lie below the Kasigau Group, a unit dominated by granulite-facies metamagmatic rocks.

To constrain the timing of events that led to this peculiar occurrence of tsavorite, we have performed geochronological analyses of thin sections and of separated grains of zircon, monazite, and rutile using LA-ICP-MS and ID-TIMS, as well as ${ }^{40} \mathrm{Ar} /{ }^{39} \mathrm{Ar}$ of muscovite and phlogopite from various lithologies. The results show that the different terranes were metamorphosed synchronously between $620-580$ Ma but under different $P-T$ strain conditions. The Kurase-HT gneisses and the rocks from the Kasigau Group are highly strained and underwent granulite-facies metamorphism with abundant partial melting and emplacement of felsic melts between 620 and $600 \mathrm{Ma}$. Textural observations also underlined a late regional water flux controlling the occurrence of $\mathrm{V}$-free muscovite and monazite mineralizations at $585 \mathrm{Ma}$. The latter event can be related to the
\end{abstract}


activity of the Galana shear zone, in the east. The Kurase-TB metasediments escaped strain and partial melting. They record amphibolite-facies conditions with static heating, since initial sedimentary structures were locally preserved. The age of the tsavorite mineralization was inferred at $600 \mathrm{Ma}$ from metamorphic zircon rims and monazite from the closest host-rocks, sampled in the mines. Hence, tsavorite crystallization occurred statically at the end of the metamorphic event, probably when the temperature and the amount of volatiles were at maximum levels.

Conversely, the ruby formed by local metasomatism of felsic dikes and isolated ultramafic bodies. The rubies are older and zircons and monazites from a ruby-bearing felsic dike (plumasite) were dated at $615 \mathrm{Ma}$. Finally, data from rutile and micas indicate a global cooling below $430{ }^{\circ} \mathrm{C}$ of the whole region between 510 and $500 \mathrm{Ma}$.

Keywords: tsavorite, zircon and monazite in situ dating, Ar-Ar dating, Kenya, Tsavo, granulite and amphibolite facies.

\section{INTRODUCTION}

The Neoproterozoic Metamorphic Mozambique Belt extends from the Arabian-Nubian Shield through East Africa, Madagascar, South India, and Sri Lanka to East Antarctica (Stern 1994, Kriegsman 1995). The NMMB resulted from the closure of the Mozambican Ocean and the accretion of different island arcs and continental blocks from 850 to $480 \mathrm{Ma}$ (Meert 2003, Collins \& Pisarevsky 2005, Fritz et al. 2013). Convergence ended with collision and the formation of the Gondwana supercontinent (Burke \& Dewey 1972, Shackleton 1996). The orogenic cycle is divided into two distinct events (Meert 2003): (1) between 750 and $620 \mathrm{Ma}$, the East Africa Orogen (Stern 1994) includes the Arabian-Nubian shield, east Africa, Madagascar, the Seychelles, north-western Pakistan, southern India, and east Antarctica; (2) between 570 and $480 \mathrm{Ma}$, the Kuunga Orogen (Meert et al. 1995) corresponds to the collision of the previously combined blocks with Antarctica and Australia.

The NMMB, also called the "Gemstone Belt of East Africa" (Malisa \& Muhongo 1990) or the "PanAfrican Gems and Graphite Belt" (Dissanayake \& Chandrajith 1999), contains many gemstone deposits with ruby, sapphire, emerald, garnets (spessartine, tsavorite, hessonite, rhodolite, "color-change" garnet), tourmaline, spinel, tanzanite, and alexandrite (Simonet et al. 2000). Some of these gems are unique and only observed in the NMMB, such as tanzanite and tsavorite (Feneyrol et al. 2013).

Tsavorite occurs sporadically in east Antarctica, Pakistan, and Madagascar, but is more abundant in Tanzania and Kenya. The gem-quality green vanadium-rich grossular is only mined in southern Madagascar (Vohibory), south-eastern Tanzania (Ruangwa and Tunduru, Fig. 1a), north-eastern Tanzania (Lelatema fold belt and Kalalani), and south-eastern Kenya from Mgama Ridge to Ngomet (Fig. 1b). The alignment of mines from Kalalani (Tanzania) towards Mgama Ridge (Kenya) defines a corridor broadly oriented $\mathrm{N} 170^{\circ}$ and extending for over a hundred kilometers, forming the largest tsavorite belt worldwide (Feneyrol et al. 2013). Metallogenetic studies of tsavorite in the Lelatema fold belt (Tanzania) have provided new models for the genesis of tsavorite (Olivier 2006, Feneyrol et al. 2010, 2013, 2017, Giuliani et al. 2014, Harris et al. 2014). The age of the tsavorite mineralization was determined using either the ages of the host rocks (Le Goff et al. 2010, Feneyrol et al. 2011) or $\mathrm{Sm} / \mathrm{Nd}$ dating of four tsavorite-bearing samples in quartz veins from Merelani, which yielded an isochron age of $606 \pm 36 \mathrm{Ma}$ (Feneyrol 2012). Until now, the age of the tsavorite formation in south-eastern Kenya has remained unknown. The closest radiometric data are for the metamorphic rocks located west of the Galana shear zone, i.e., the Sagala and Taita Hills gneisses (Fig. 2), metamorphosed between 660 and $630 \mathrm{Ma}$ (Hauzenberger et al. 2007, Bauernhofer et al. 2008). The metamorphism was developed during thrusting of nappes in the east-west direction (Fritz et al. 2013).

In this paper we aim to better constrain the timing of the different metamorphic events affecting an area extending from Kalalani (Tanzania) to the Mgama Ridge (Kenya) and especially the age of the metamorphism leading to tsavorite formation. We integrated field observations with structural and petrographic studies of two adjacent metamorphic Groups, i.e., the Kasigau and the Kurase (Fig. 2). For the Kurase Group, we made the distinction between tsavoritebearing metasediments and high-temperature gneisses. We used in situ U-Th-Pb dating by LA-ICP-MS of zircon, monazite, and rutile, complemented by IDTIMS dating of dissolved zircon and monazite. We also used ${ }^{40} \mathrm{Ar} /{ }^{39} \mathrm{Ar}$ dating of micas. The set of radiometric data allowed us to (1) define the ages of the different metamorphic units, (2) revise the age of tsavorite formation as well as the formation of a rubybearing metapegmatite, and (3) determine the cooling age of the metamorphic pile. At the regional scale, knowledge of the age of gem formation and metamorphism will result in a better understanding of the thermal evolution of the NMMB. 


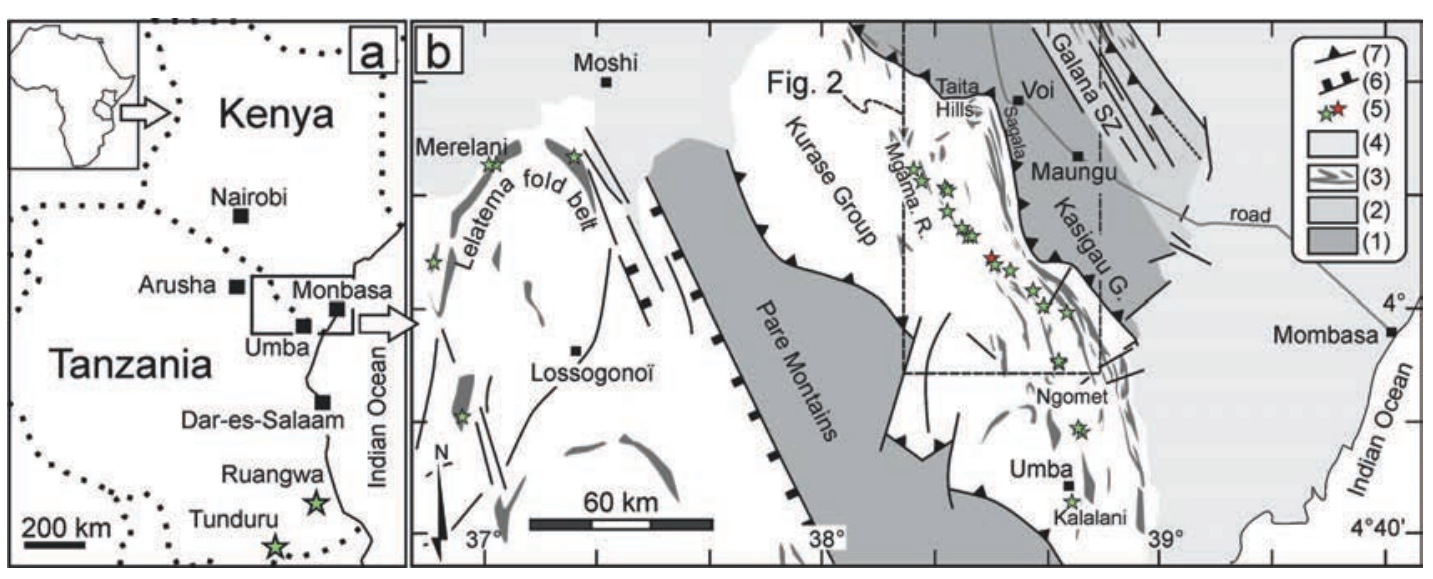

FIG. 1. Simplified geological map showing tsavorite occurrences in eastern Africa. (1) Metamagmatic rocks undivided, (2) granulitic rocks undivided, (3) undivided metasediments hosting marbles, (4) Karoo sediments and Neogene volcanics, (5) tsavorite occurrences in green, and Rockland ruby mine in red, (6) Normal fault, (7) Thrust zone (modified from Fritz et al. 2009, Le Goff et al. 2010, Feneyrol et al. 2013).

\section{Geological Setting}

The studied area extends between the east and west Tsavo National parks and includes the town of Voi (Figs. 1b, 2), located on the main road and railway linking Nairobi to Mombasa. It notably consists of the Kasigau and Kurase Groups, which are framed to the east by a $25 \mathrm{~km}$-wide granulitic vertical wrench zone called the Galana shear zone (Fig. 2) dated at 580-550 Ma (Hauzenberger et al. 2007, Bauernhofer et al. 2008). Detailed geological descriptions of the Kasigau and Kurase Groups are available in several reports and associated maps (Sanders 1963, Pohl \& Niedermayr 1979, Pohl et al. 1980, Saggerson 1962, Frisch \& Pohl 1986), as well as in more recent works (Mercier et al. 1999, Simonet 2000, Hauzenberger et al. 2007, Bauernhofer et al. 2008, Wamunyu et al. 2015). We have summarized and added to them in the following sections.

\section{Geological setting of the Kasigau Group}

Lithology. The Kasigau Group is dominated by quartzo-feldspathic \pm garnet amphibolitic to biotitic gneisses where the highly aluminous rocks contain sillimanite or kyanite or both. Other rocks are clinopyroxene-bearing amphibolites \pm wollastonitebearing marbles, or calc-silicate layers showing biotite and amphibole replaced by orthopyroxene. Partial melting is intense and the metasedimentary rocks can be assimilated, forming metric dismembered lenses inside the quartzo-feldspathic migmatitic gneisses.

Neoproterozoic metamorphism. Hauzenberger et al. $(2004,2005)$ estimated metamorphic peak condi- tions of $820{ }^{\circ} \mathrm{C}$ and $11-12$ kbar using several geothermobarometers and different lithologies (felsic gneisses and mafic rocks). This metamorphism is Neoproterozoic (665-615 Ma; Hauzenberger et al. 2007). A metamorphic overprint at amphibolite-facies conditions $\left(590-700{ }^{\circ} \mathrm{C}\right.$ and $\left.6-10 \mathrm{kbar}\right)$ is locally indicated by new muscovite growth from sillimanite and actinolite growth around hornblende. These retrograde phases grow both parallel and perpendicular to the schistosity, attesting to their post-tectonic character.

Structure. The metamorphic foliation is flat or shallowly dipping $30^{\circ}$ to the east or the northnortheast. Ductile deformation is widespread and indicated by recumbent isoclinal folds and boudinage. Partial melting is important and sometimes leucosomes migrate into dilatant structures between boudins. The Kasigau Group is thrust over the Kurase Group. In the Taita Hills, serpentinized ultramafic rocks localized in the highly strained rocks of the thrust zone have been interpreted as an ophiolitic suture (Fig. 2, Frisch \& Pohl 1986).

\section{Geological setting of the Kurase Group}

Lithology. Based on petrologic criteria, the Kurase Group has been described as a lithostratigraphic succession (from bottom to top): the Mtongore Formation, the Lualenyi Member, the Mgama-Mindi Formation including the Mtonga-Kore unit, the Mwatate Formation, and the Mugeno Formation (Pohl \& Niedermayr 1979, Horkel et al. 1979, Pohl et al. 1980, Saggerson 1962). 


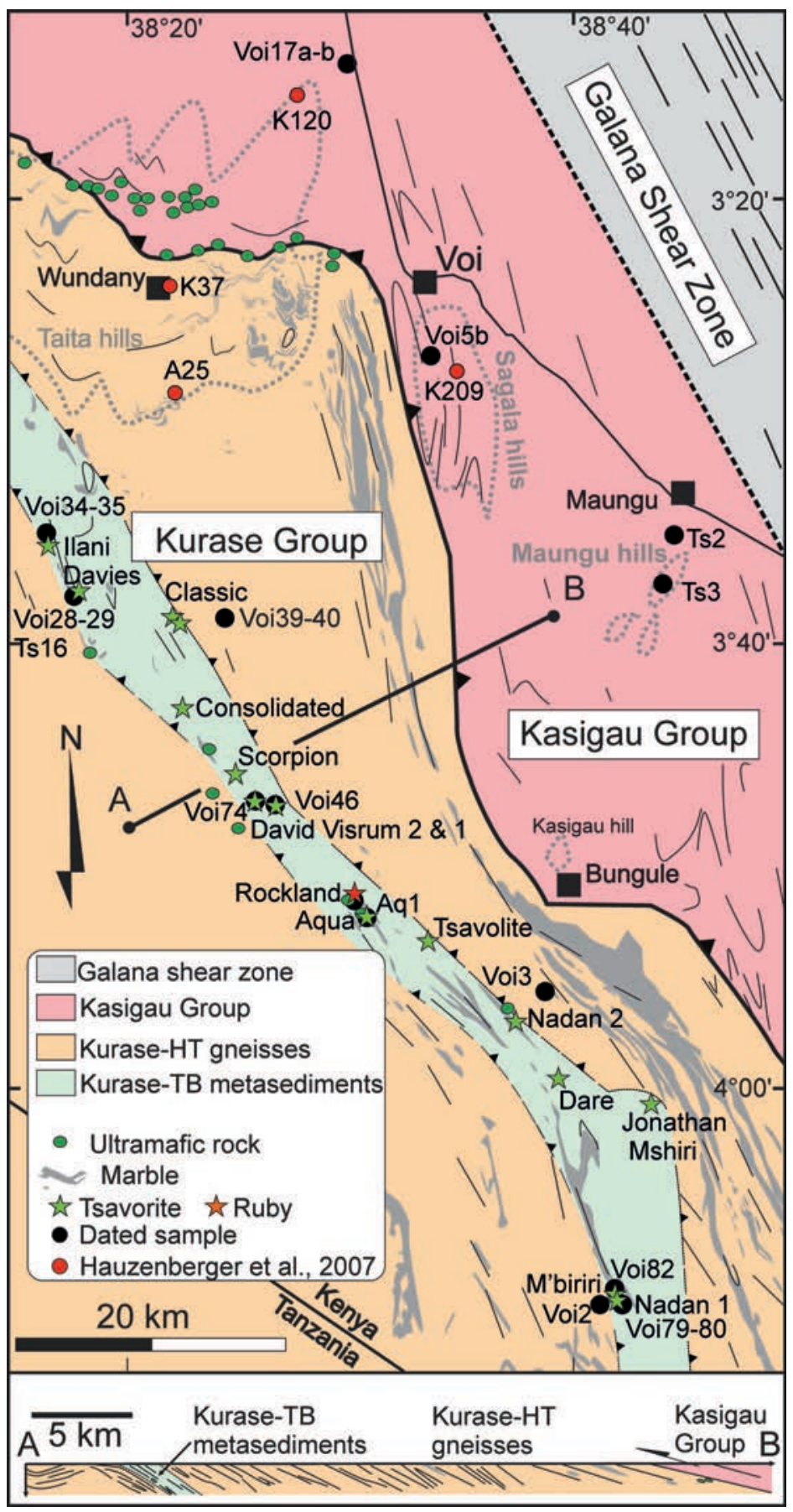

FIG. 2. Simplified cross-section and geological map with locations of samples discussed in the text (modified from Pohl \& Niedermayr 1979, Horkel et al. 1979, Pohl et al. 1980, Saggerson 1962, Simonet 2000, Hauzenberger et al. 2007, Bauernhofer et al. 2008, Feneyrol et al. 2013). 
The Mtongore, Mwatate, and Mugeno Formations, as well as the Mtonga-Kore unit, are called the Kurase high-temperature gneisses (Kurase-HT gneisses) in the present study. They are dominated by migmatitic biotitic gneisses. Other lithologies such, as marbles and felsic charnockites, are also present.

The tsavorite-bearing Lualenyi member and MgamaMindi Formation are called the Kurase tsavorite-bearing metasediments (Kurase-TB metasediments) in the present study. The metasediments are mainly muscovitegraphite-bearing gneisses which also contain sillimanite or kyanite or both, intercalated with meter- to several decameter-scale bands of meta-arenites and rudites, quartzites, and marbles (Wamunyu et al. 2015), and a few amphibolites. Tsavorite nodules are observed exclusively in graphitic gneisses and scapolite-diopsideanhydrite-bearing calc-silicate rocks (Suwa et al. 1996, Feneyrol et al. 2013). In a few places, primary sedimentary structures such as cross-stratification and channels are preserved. At the centimeter scale, sedimentary textures are also visible, such as large detritic K-feldspar crystals containing green detritic uvite tourmaline (Martelat et al. 2015). In the Kurase-TB metasediments, migmatization is rare. Intrusive felsic magmatic dikes have been observed. One of these dikes crosscuts isolated ultramafic bodies at the Rockland ruby mine (Simonet 2000).

Neoproterozoic metamorphism. The Kurase-HT gneisses show migmatization and granulite-facies parageneses (e.g., charnockites composed of plagioclase, K-feldspar, hornblende, hypersthene, diopside, and some quartz, Pohl \& Niedermayr 1979). Pressuretemperature conditions and ages of the metamorphism are similar to those of the Kasigau Group $\left(820^{\circ} \mathrm{C}\right.$, $11-$ $12 \mathrm{kbar}$ at 660-630 Ma, Hauzenberger et al. 2004, $2005,2007)$. A retrogression in the amphibolite facies is assumed for the Kurase-HT gneisses located in the Taita Hills (Hauzenberger et al. 2004, Pohl \& Niedermayr 1979). The latter developed during slow cooling (3-5 ${ }^{\circ} \mathrm{C} / \mathrm{my}$, Hauzenberger et al. 2005).

The Kurase-TB metasediments parageneses reflect lower $P$ and $T$ conditions than the Kurase-HT gneisses (rare migmatization, widespread occurrence of large muscovite crystals, Pohl \& Niedermayr 1979). Few quantitative data are available for this unit. Genetic models of tsavorite formation have shown that the transformation of diopside to tsavorite occurred isochemically in a static regime without metasomatism at $7 \mathrm{kbar}$ and $680{ }^{\circ} \mathrm{C}$ (Feneyrol et al. 2013). This is in agreement with $P-T$ conditions estimated for the Rockland mine. Thermobarometry applied to the garnet-biotite-sillimanite-graphite-bearing gneisses yields temperature and pressure in the amphibolite facies $\left(650{ }^{\circ} \mathrm{C}, 7 \mathrm{kbar}\right.$, Mercier et al. 1999). Locally, parageneses of the ruby-bearing plagioclasite (e.g., sapphirine embedded in micas) and the associated metamorphosed ultrabasites are consistent with their formation under granulite-facies conditions $(T=700$ $750{ }^{\circ} \mathrm{C}$ and $P=8-10.5 \mathrm{kbar}$, Mercier et al. 1999). The ruby formation is associated with local metasomatism, with fluids that transformed the pegmatite in ruby \pm apatite \pm uvite \pm phlogopite-bearing plagioclasite, and the adjacent ultramafic rocks in phlogopitites. In this case, the metasomatism is controlled by the intrusion of felsic magmatic dikes.

Structure. In the Kurase-TB metasediments, foliation dips east or north-northeast at around $30^{\circ}$. This metamorphic plane is parallel to the original stratification. Sedimentary figures such as cross-stratification and channels can be observed (Martelat et al. 2015). Thus the Kurase-TB metasediments escaped both partial melting and strain. The two contacts between the Kurase-HT gneisses and the Kurase-TB metasediments are not visible in the field due to poor exposure. Nevertheless, the contacts are sharp (a few meters thick) and the fabric is conformable on both sides. These two contacts are considered to be thrust zones (Fig. 2; Pohl \& Niedermayr 1979, Pohl et al. 1980).

\section{Analytical Methods}

Fourteen localities were selected for geochronology and a set of more than 20 samples were dated: five samples from the Kasigau Group, four from the Kurase-HT gneisses, and 13 samples from the Kurase-TB metasediments. Rocks were characterized by optical microscopy and in situ chemical analyses using a CAMECA SX100 electron microprobe at the Laboratoire Magmas et Volcans (Clermont-Ferrand, France) and at CRPG (Nancy, France) operated at 15 $\mathrm{kV}$ and $15 \mathrm{nA}$ for a $1 \mu \mathrm{m}$ beam size and using TAP and LIF crystals.

In situ U-Th- $\mathrm{Pb}$ isotopic data were obtained by laser ablation inductively coupled plasma spectrometry (LA-ICP-MS) at the Laboratoire Magmas et Volcans (Clermont-Ferrand, France). The analyses involved the ablation of minerals with a Resonetics Resolution M-50 instrument incorporating an ultrashort pulse $(<4 \mathrm{~ns})$ ATL Atlex Excimer laser system operating at a wavelength of $193 \mathrm{~nm}$ (detailed description in Müller et al. 2009). Spot diameters of 15-26 $\mu \mathrm{m}$ and 9-15 $\mu \mathrm{m}$, repetition rates of 3 and $1 \mathrm{~Hz}$, and laser fluences of 4 and $15 \mathrm{~J} / \mathrm{cm}^{2}$ were used for the zircon and monazite, respectively (Supplementary Tables 1 and 2, available from the MAC Depository of Unpublished Data, document tsavorite CM555_10.3749/canmin.1700019). The ablated material was carried by helium and then mixed with nitrogen and argon before injection into the plasma source of an 
Agilent 7500 cs ICP-MS equipped with a dual pumping system to enhance sensitivity (Paquette et al. 2014). The alignment of the instrument and mass calibration were performed before every analytical session using the NIST SRM 612 reference glass by inspecting the ${ }^{238} \mathrm{U}$ signal and by minimizing the $\mathrm{ThO}+\mathrm{Th}+$ ratio $(<1 \%)$. The analytical method for isotope dating is similar to that developed and described in Paquette \& Tiepolo (2007) and Didier et al. (2013) and detailed in Hurai et al. (2010). The signals of the ${ }^{204}(\mathrm{~Pb}+\mathrm{Hg}),{ }^{206} \mathrm{~Pb},{ }^{207} \mathrm{~Pb},{ }^{208} \mathrm{~Pb},{ }^{232} \mathrm{Th}$, and ${ }^{238} \mathrm{U}$ masses were measured. The occurrence of common $\mathrm{Pb}$ in the sample was monitored by the evolution of the ${ }^{204}(\mathrm{~Pb}+\mathrm{Hg})$ signal intensity, but no common $\mathrm{Pb}$ correction was applied owing to the large isobaric interference from $\mathrm{Hg}$. The ${ }^{235} \mathrm{U}$ signal was calculated from ${ }^{238} \mathrm{U}$ on the basis of the ratio ${ }^{238} \mathrm{U} /{ }^{235} \mathrm{U}=137.88$. A single analysis consisted of $30 \mathrm{~s}$ of background integration with the laser off, followed by $60 \mathrm{~s}$ integration with the laser firing, and a $20 \mathrm{~s}$ delay to wash out the previous sample and prepare for the next analysis.

Data were corrected for U-Pb fractionation occurring during laser sampling and for instrumental mass discrimination (mass bias) by standard bracketing with repeated measurements of the GJ-1 zircon reference material (Jackson et al. 2004). Repeated analyses of the 91500 zircon reference material (Wiedenbeck et al. 1995) and of the C83-32 monazite (Corfu 1988, Didier 2013 ) treated as an unknown independently controlled the reproducibility and accuracy of the corrections. Data reduction was carried out with the software package GLITTER ${ }^{\circledR}$ from Macquarie Research Ltd. (van Achterberg et al. 2001, Jackson et al. 2004). For each analysis, the time-resolved signals of single isotopes and isotope ratios were monitored and carefully inspected to verify the presence of perturbations related to inclusions, fractures, mixing of different age domains, or common $\mathrm{Pb}$. Calculated ratios were exported and concordia ages and diagrams were generated using the Isoplot/Ex v. 2.49 software package of Ludwig (2001). The zircon analytical results were projected on ${ }^{207} \mathrm{~Pb} /{ }^{206} \mathrm{~Pb}$ versus ${ }^{238} \mathrm{U} /{ }^{206} \mathrm{~Pb}$ plots (Tera \& Wasserburg 1972) or concordia diagrams according to their readability. The monazite analyses are reported either on $\mathrm{U}-\mathrm{Th}-\mathrm{Pb}$ or Tera Wasserburg diagrams, depending on the common- $\mathrm{Pb}$ content. The concentrations of $\mathrm{U}-\mathrm{Th}-\mathrm{Pb}$ were calibrated relative to the values of the GJ-1 zircon reference material (Jackson et al. 2004) and to the C83-32 monazite (Corfu 1988, Didier 2013).

The ID-TIMS analyses were performed following the techniques described in Paquette \& Pin (2001) and Quidelleur et al. (2011).
The full set of data is presented in Supplementary Table 1 (LA-ICP-MS Zrn + Rt), Table 2 (LA-ICP-MS Mnz), and Table 3 (ID-TIMS Zrn + Mnz).

Before dating, the zircon crystals were imaged by cathodoluminescence to investigate their inner structure and zoning. Imaging was performed using a JEOL JSM-5910LV scanning electron microscope (SEM) equipped with a detector operating at $15 \mathrm{kV}$ current at the Laboratoire Magmas et Volcans (ClermontFerrand, France). The monazites were analyzed either as separated grains mounted in epoxy resin or in thin section. Textures and chemical zonation were studied with a SEM SupraZeiss $55 \mathrm{VP}$ at Laboratoire de Géologie de Lyon (France) and with the CAMECA SX100 electron microprobe at the Laboratoire Magmas et Volcans (Clermont-Ferrand, France).

Samples selected for ${ }^{40} \mathrm{Ar} /{ }^{39} \mathrm{Ar}$ dating were crushed and sieved; single grains of mica of about $0.5 \mathrm{~mm}$ in diameter were then handpicked using a binocular microscope and cleaned in an ultrasonic bath using acetone and distilled water. The minerals were packaged in $\mathrm{Al}$ foil and irradiated for $40 \mathrm{~h}$ in the core of the Triga Mark II nuclear reactor at Pavia (Italy) with several aliquots of the Taylor Creek anidine standard (28.34 $\pm 0.10 \mathrm{Ma})$ as a flux monitor. Argon isotopic interferences on $\mathrm{K}$ and $\mathrm{Ca}$ were determined by irradiation of $\mathrm{KF}$ and $\mathrm{CaF}_{2}$ pure salts from which the following correction factors were obtained: $\left({ }^{40} \mathrm{Ar} /{ }^{39} \mathrm{Ar}\right)_{\mathrm{K}}=0.00969 \pm 0.00038$, $\left({ }^{38} \mathrm{Ar} /{ }^{39} \mathrm{Ar}\right)_{\mathrm{K}}=0.01297 \pm 0.00045,\left({ }^{39} \mathrm{Ar} /{ }^{37} \mathrm{Ar}\right)_{\mathrm{Ca}}=$ $0.0007474 \pm 0.000021$, and $\left({ }^{36} \mathrm{Ar} /{ }^{37} \mathrm{Ar}\right)_{\mathrm{Ca}}=$ $0.000288 \pm 0.000016$. Argon analyses were performed at Géosciences Montpellier (France) with an analytical system that consists of: (1) an IR- $\mathrm{CO}_{2}$ laser of $100 \mathrm{kHz}$ used at $5-15 \%$ for $30 \mathrm{~s}$ for step-heating experiments, (2) a system of lenses for beam focusing, (3) a steel sample chamber, maintained at $10^{-8}-10^{-9}$ bar, with a drilled copper plate for the samples, (4) an inlet line for purification of gases including two Zrn-Al traps, and (5) a multi-collector mass spectrometer (Argus VI from Thermo-Fisher). A custom-made software program controls the laser intensity, the timing of extraction/purification, and the data acquisition. The argon background within the system was evaluated every three sample analyses. The ArArCalc software $\left(\mathrm{v}^{2}\right.$ 2.5.2 was used for data reduction and plotting. The one-sigma errors reported for the plateau, isochron, and total gas ages include the error on the irradiation factor J. Atmospheric ${ }^{40} \mathrm{Ar}$ was estimated using a value for the initial ${ }^{40} \mathrm{Ar} /{ }^{36} \mathrm{Ar}$ of 295.5. Due to the high radiogenic content of the dated micas, the data reported in the ${ }^{36} \mathrm{Ar} /{ }^{40} \mathrm{Ar}$ versus ${ }^{39} \mathrm{Ar} /{ }^{40} \mathrm{Ar}$ correlation plot do not provide meaningful information on the composition of the initially 
trapped argon. A complete set of isotopic results is available in Supplementary Table 4.

\section{SAmple Descriptions}

The dominant petrographic features of the rocks selected for dating are presented in Figure 3 and in the text below. For each of them, the dated phase is provided in brackets as follows: zircon ( $\mathrm{Zrn})$, monazite $(\mathrm{Mnz})$, rutile (Rt), phlogopite (Phl), and muscovite (Msc).

For the Kasigau Group, six samples were dated (Fig. 2): Voi17a (Zrn), Voi17b (Zrn), Voi5b (Zrn), Ts2 (Mnz-Msc), and Ts3 (Zrn-Mnz). They all underwent partial melting. Sample Voi17a is a migmatitic gneiss with rare garnet and green amphibole. Sample Voi17b is a leucocratic allochtonous melt with biotite and green amphibole localized in dilatant structures crosscutting the migmatitic foliation of Voi17a. Voi5b, collected in the Sagala Hills, is an in situ leucosome (quartz-feldspath-garnet-bearing rock, Fig. 3a) segregated in an amphibolitic migmatitic gneiss. Samples Ts2 and Ts3 are from the Maungau-Nyngala Hills. Sample Ts2 (Fig. 3b) is an aluminous layer rich in quartz, biotite, muscovite, and sillimanite. The sillimanite is partly retrogressed, resulting in large flakes of V-free muscovite (Fig. 3b, Table 1). Sample Ts3 is a garnet-biotite-bearing stromatic migmatite.

Four samples were dated from the Kurase-HT gneisses: Voi39 (Zrn), Voi40 (Zrn), Voi2a (Zrn), and Voi3 (Mnz). Sample Voi39 is a segregated leucosome composed of equilibrated grains of quartz and plagioclase, and of large multi-millimeter-long perthitic K-feldspar crystals (Fig. 3c). Sample Voi40 is a quartzo-feldspathic leucosome with oriented magnetite grains (millimetric in length) underlying a disrupted foliation. Samples Voi2a and Voi3 are felsic granulites displaying stromatic migmatitic textures and containing garnet, quartz, plagioclase, and K-feldspar with exsolved lamellae of albite. They exhibit dehydration melting of biotite resulting in peritectic garnet. In Voi3 small V-free muscovite crystals are found in discrete fractures which post-date the granulitic foliation plane (Fig. 3d, Table 1).

Eleven samples of the Kurase-TB metasediments were collected from mines or quarries: Voi28 (Zrn, Mnz), Voi29 (Zrn, Phl), Voi34-Voi35 (Mnz, Msc), Voi74 (Zrn), Voi79-Voi80 (Zrn, Rt), Voi82 (Msc), Aq1 (Phl), Ts16 (Msc), and Rockland (Mnz, Zrn). They can be separated into four groups: (1) metarudites, (2) graphitic gneisses, (3) veins filled with muscovite, and (4) metasomatic desilicated pegmatites at Rockland.

The meta-rudites (Voi28, Voi29, Voi35) are composed of quartz, K-feldspar, plagioclase, graphite, and muscovite (muscovite from Voi28 and Voi29 contains V; Voi29: $\mathrm{V}_{2} \mathrm{O}_{3}=0.31$ wt.\%, Table 1, Fig. 3e). Sample Voi29 also contains F-rich phlogopite (1.45 wt.\%, Table 1). Samples Voi28 and Voi29 have been preserved from strain and show sedimentary texture and structure. Sample Voi35 is slightly strained and contains $\mathrm{V}$-free muscovite (Table 1).

The graphitic gneisses (Voi34, Voi74, Voi79, Voi80, Fig. 3f) are aluminous quartzo-feldspathic rocks with sillimanite and locally kyanite. This lithology contains the calc-magnesian nodules in which tsavorite is observed (Giuliani et al. 2014). In sample Voi34, both sillimanite and muscovite with high $\mathrm{V}$ and Ti contents can be observed (Fig. 3 f, $\mathrm{V}_{2} \mathrm{O}_{3}$ $=1.75$ wt. $\%, \mathrm{TiO}_{2}=1.27$ wt. $\%$, Table 1). Muscovite seems to develop at the expense of sillimanite, but the reverse situation is also visible.

Sample Voi82 comes from a vein filled with quartz, kyanite, muscovite, and green tourmaline, which cross-cuts the graphitic metasediments (Fig. 3g). The separated muscovite contains $\mathrm{V}$ and $\mathrm{Ti}\left(\mathrm{V}_{2} \mathrm{O}_{3}=0.46\right.$ wt. $\%, \mathrm{TiO}_{2}=2.02 \mathrm{wt} . \%$, Table 1). In the Aqua mine (sample Aq1), phlogopite occurs in monomineralic veins cross-cutting the main fabric of a ruby-bearing desilicated felsic dike (Fig. 3h, Table 1). In sample Ts16 the vein is horizontal in a boudin of marble within the graphitic gneiss. Indeed, V-free micas are associated with quartz, zoisite, tourmaline, and graphite (Table 1). These last three occurrences of micas were considered to be representative of the latest crystallized micas.

The desilicated pegmatites (Rockland mine from the Kimbo "pit") are the unique metasomatic rocks formed close to, or at the contact with, the serpentinized ultrabasic rocks. They contain ruby as well as green tourmaline.

\section{U-Th-Pв Geochronological Results}

\section{Kasigau Group}

For the stromatic migmatite sample Voi17a, 45 spots in the cores of translucent zircons yielded a concordia age of $884.8 \pm 2.3$ Ma (Fig. 4a; Supplementary Table 1). Nine spots were focused on fine rims which are Th-depleted and characterized by $\mathrm{Th} / \mathrm{U}$ ratios mostly lower than 0.01 . They provided a younger concordia age, $615.6 \pm 4.6 \mathrm{Ma}$, than was provided by the cores.

The Voi17b secant leucosome contains U-rich zircons $(600<\mathrm{U}<2000 \mathrm{ppm})$ which are darker than the well-shaped crystals from sample Voi17a. When the most metamict grains (i.e., $\mathrm{U}$ content up to $3000 \mathrm{ppm}$ ) containing common lead are excluded and the best-preserved zircon surfaces are selected, the analytical points define a discordia line with a lower 

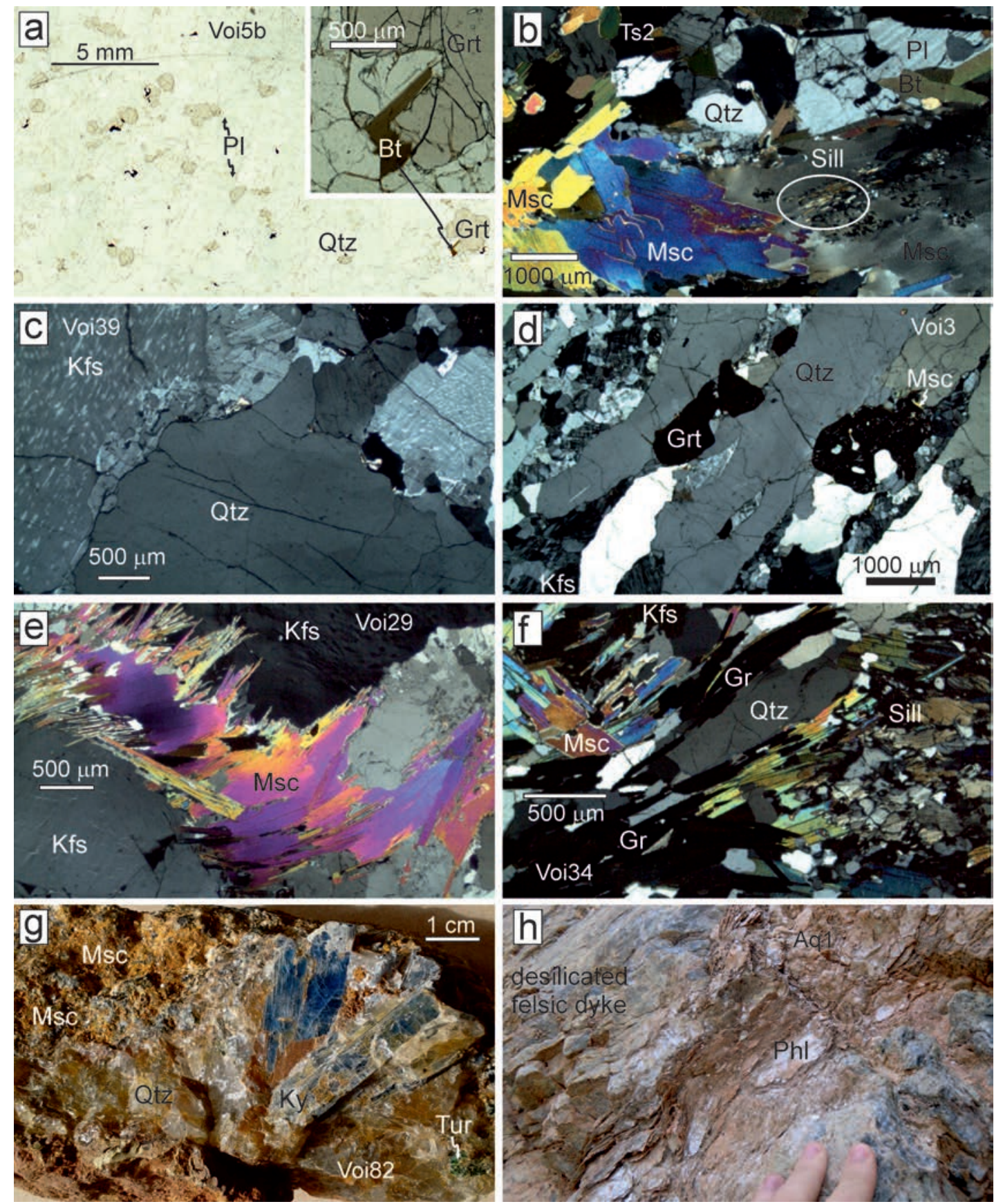

FIG. 3. Images showing the texture of representative dated samples. In the Kasigau Group: (a) Voi5b (Sagala hills) is an in situ leucosome; (b) Ts2 (Maungau-Nyngala hills) is an aluminous layer (sillimanite is partly retrogressed, giving large muscovite grains that can be oriented at a high angle to the foliation). In the Kurase-HT gneisses: (c) Voi39 is a leucosome; (d) Voi3 is a felsic granulite (small muscovite grains are found in discrete fractures). In the Kurase-TB metasediments: (e) Voi29 is a metarudite with V-rich muscovite; (f) Voi34 is a graphitic gneiss (this lithology contains the calc-magnesian nodules in which tsavorite is observed); (g) Voi82 is a vein filled with quartz, kyanite, muscovite, and Cr-rich tourmaline; (h) Aq1 is phlogopite forming mono-mineral veins cross-cutting the main fabric of a ruby-bearing desilicated felsic dike. 
TABLE 1. REPRESENTATIVE MUSCOVITE AND PHLOGOPITE ANALYSES

\begin{tabular}{|c|c|c|c|c|c|c|c|c|c|c|}
\hline \multirow{2}{*}{$\begin{array}{l}\text { Mineral } \\
\text { Sample } \\
\end{array}$} & \multicolumn{7}{|c|}{ Muscovite } & \multicolumn{3}{|c|}{ Biotite } \\
\hline & Ts2 & Voi82 & Voi29 & Voi34 & Voi35 & Ts16 & Voi3 & Sample & Voi29 & $A q 1$ \\
\hline $\mathrm{SiO}_{2}$ (wt.\%) & 45.47 & 48.34 & 46.24 & 46.50 & 46.96 & 47.82 & 45.60 & $\mathrm{SiO}_{2}$ & 40.77 & 40.58 \\
\hline $\mathrm{TiO}_{2}$ & 0.91 & 2.02 & 3.14 & 1.27 & 0.12 & 0.42 & 0.33 & $\mathrm{TiO}_{2}$ & 1.97 & 0.59 \\
\hline $\mathrm{Al}_{2} \mathrm{O}_{3}$ & 32.60 & 33.21 & 32.99 & 31.97 & 35.04 & 31.60 & 35.63 & $\mathrm{Al}_{2} \mathrm{O}_{3}$ & 18.47 & 17.29 \\
\hline $\mathrm{Cr}_{2} \mathrm{O}_{3}$ & 0.00 & 0.09 & 0.00 & 0.18 & 0.01 & 0.02 & 0.01 & $\mathrm{Cr}_{2} \mathrm{O}_{3}$ & 0.02 & 0.37 \\
\hline $\mathrm{V}_{2} \mathrm{O}_{3}$ & 0.00 & 0.46 & 0.31 & 1.75 & 0.00 & 0.09 & 0.00 & $\mathrm{~V}_{2} \mathrm{O}_{3}$ & 0.28 & 0.03 \\
\hline $\mathrm{FeO}$ & 3.60 & 0.00 & 0.12 & 0.07 & 0.02 & 0.04 & 1.84 & $\mathrm{FeO}$ & 0.91 & 0.24 \\
\hline $\mathrm{MnO}$ & 0.02 & 0.00 & 0.01 & 0.00 & 0.03 & 0.05 & 0.01 & $\mathrm{MnO}$ & 0.34 & 0.00 \\
\hline $\mathrm{MgO}$ & 0.97 & 2.03 & 2.15 & 1.91 & 1.16 & 3.31 & 0.28 & $\mathrm{MgO}$ & 23.19 & 24.73 \\
\hline $\mathrm{CaO}$ & 0.03 & 0.00 & 0.02 & 0.00 & 0.00 & 0.00 & 0.00 & $\mathrm{CaO}$ & 0.00 & 0.00 \\
\hline $\mathrm{Na}_{2} \mathrm{O}$ & 0.50 & 0.44 & 0.38 & 0.31 & 0.43 & 0.23 & 1.02 & $\mathrm{Na}_{2} \mathrm{O}$ & 0.08 & 0.12 \\
\hline $\mathrm{K}_{2} \mathrm{O}$ & 10.79 & 8.94 & 10.81 & 11.01 & 11.28 & 9.63 & 10.00 & $\mathrm{~K}_{2} \mathrm{O}$ & 9.05 & 8.63 \\
\hline $\mathrm{F}$ & 0.04 & 0.08 & 0.10 & 0.07 & 0.06 & 0.00 & 0.02 & $\mathrm{~F}$ & 1.45 & 1.86 \\
\hline \multirow[t]{2}{*}{ Total } & 94.93 & 95.61 & 96.27 & 95.05 & 95.11 & 93.21 & 94.74 & Total & 96.51 & 94.45 \\
\hline & \multicolumn{7}{|c|}{$\begin{array}{l}\text { Structural formulae calculated } \\
\text { on the basis of } 110 \mathrm{pfu}\end{array}$} & \multicolumn{3}{|c|}{$\begin{array}{l}\text { Structural formulae } \\
\text { on the basis of } 220 \mathrm{pfu}\end{array}$} \\
\hline $\mathrm{Si}$ & 3.091 & 3.16 & 3.055 & 3.119 & 3.122 & 3.214 & 3.058 & $\mathrm{Si}$ & 5.642 & 5.731 \\
\hline $\mathrm{Al}^{\mathrm{IV}}$ & 0.909 & 0.84 & 0.945 & 0.881 & 0.878 & 0.786 & 0.942 & $\mathrm{Al}^{\mathrm{IV}}$ & 2.358 & 2.269 \\
\hline $\mathrm{Al}^{\mathrm{VI}}$ & 1.702 & 1.72 & 1.624 & 1.646 & 1.868 & 1.718 & 1.874 & $\mathrm{Al}^{\mathrm{VI}}$ & 0.654 & 0.609 \\
\hline $\mathrm{Ti}$ & 0.047 & 0.10 & 0.156 & 0.064 & 0.006 & 0.021 & 0.017 & $\mathrm{Ti}$ & 0.205 & 0.063 \\
\hline $\mathrm{Cr}$ & 0.000 & 0.00 & 0.000 & 0.010 & 0.001 & 0.001 & 0.000 & $\mathrm{Cr}$ & 0.002 & 0.041 \\
\hline V & 0.000 & 0.01 & 0.016 & 0.094 & 0.000 & 0.005 & 0.000 & V & 0.016 & 0.002 \\
\hline $\mathrm{Fe}$ & 0.205 & 0.00 & 0.007 & 0.004 & 0.001 & 0.002 & 0.103 & $\mathrm{Fe}$ & 0.105 & 0.028 \\
\hline $\mathrm{Mn}$ & 0.001 & 0.00 & 0.001 & 0.000 & 0.002 & 0.003 & 0.000 & $\mathrm{Mn}$ & 0.040 & 0.000 \\
\hline $\mathrm{Mg}$ & 0.099 & 0.20 & 0.211 & 0.191 & 0.115 & 0.332 & 0.028 & $\mathrm{Mg}$ & 4.784 & 5.207 \\
\hline $\mathrm{Ca}$ & 0.002 & 0.00 & 0.001 & 0.000 & 0.000 & 0.000 & 0.000 & $\mathrm{Ca}$ & 0.000 & 0.000 \\
\hline $\mathrm{Na}$ & 0.066 & 0.06 & 0.048 & 0.040 & 0.055 & 0.030 & 0.133 & $\mathrm{Na}$ & 0.021 & 0.033 \\
\hline K & 0.936 & 0.75 & 0.911 & 0.942 & 0.957 & 0.826 & 0.855 & $\mathrm{~K}$ & 1.597 & 1.555 \\
\hline \multirow[t]{2}{*}{ Total } & 7.057 & 6.83 & 6.976 & 6.992 & 7.005 & 6.938 & 7.011 & Total & 7.011 & 7.011 \\
\hline & & & & & & & & XMg & 0.98 & 0.99 \\
\hline
\end{tabular}

intercept at $598.8 \pm 3.8 \mathrm{Ma}$ (Fig. 4b; Supplementary Table 1).

Zircon from Voi5b segregated leucosomes is characterized by two different habits: elongated or more rounded grains. Both crystal types record large variations of $U$ content ranging from less than 50 up to $700 \mathrm{ppm}$. No correlation between shape, U content, and calculated ages was established. An imprecise concordia age of $884 \pm 27$ Ma can be calculated, the latter being compatible with the older age of Voi17a. The 36 remaining spots, including 13 rims (data in red in Fig. 4c; Supplementary Table 1) yield a lower intercept age at $611.6 \pm 3.9 \mathrm{Ma}$ (Fig. 4c).

The aluminous layer (sample Ts2) contains rare elongated subeuhedral monazite grains included in biotite (Fig. 5a). Thirteen in situ analyses obtained from two crystals yield a concordant Th-U-Pb age of $584 \pm 5 \mathrm{Ma}$ (Fig. 4d; Supplementary Table 2). The Th content is between 10,770 and $25,000 \mathrm{ppm}$ and the $\mathrm{U}$ content is high at between 3700 and $9000 \mathrm{ppm}$. The $\mathrm{Th} / \mathrm{U}$ ratios are low $(1.8<\mathrm{Th}<4.1)$.

The Ts3 migmatitic gneiss contains rare zircon (Fig. 5b, c). Twenty-nine spots from zircon cores yielded a concordia age of $743.8 \pm 4.4 \mathrm{Ma}$ (Fig. 4e; Supplementary Table 1$)$. These cores display typically magmatic $\mathrm{Th} / \mathrm{U}$ ratios $(0.2<\mathrm{Th} / \mathrm{U}<0.4-0.5)$. Thirteen spots on the rims provided a concordia age of $610.5 \pm 4.3 \mathrm{Ma}$ (Fig. 4e). These rims are characterized by higher $\mathrm{U}$ and lower Th contents than the cores, resulting in low $\mathrm{Th} / \mathrm{U}$ ratios $(\mathrm{Th} / \mathrm{U}<0.1)$. This trend is quite similar to what is observed in sample Voi17a, both rim ages being comparable. The five monazite grains separated from sample Ts3 are a bit cloudy, rounded, and fractured, 100 to $200 \mu \mathrm{m}$ wide. The Th-U-Pb analyses display two groups of ages (Fig. 4f; Supplementary Table 2). The first group (18 analyses from four grains) yielded a concordant age of $585 \pm 4 \mathrm{Ma}$. The second group (14 analyses from three grains) yielded a concordant age of $516 \pm$ 

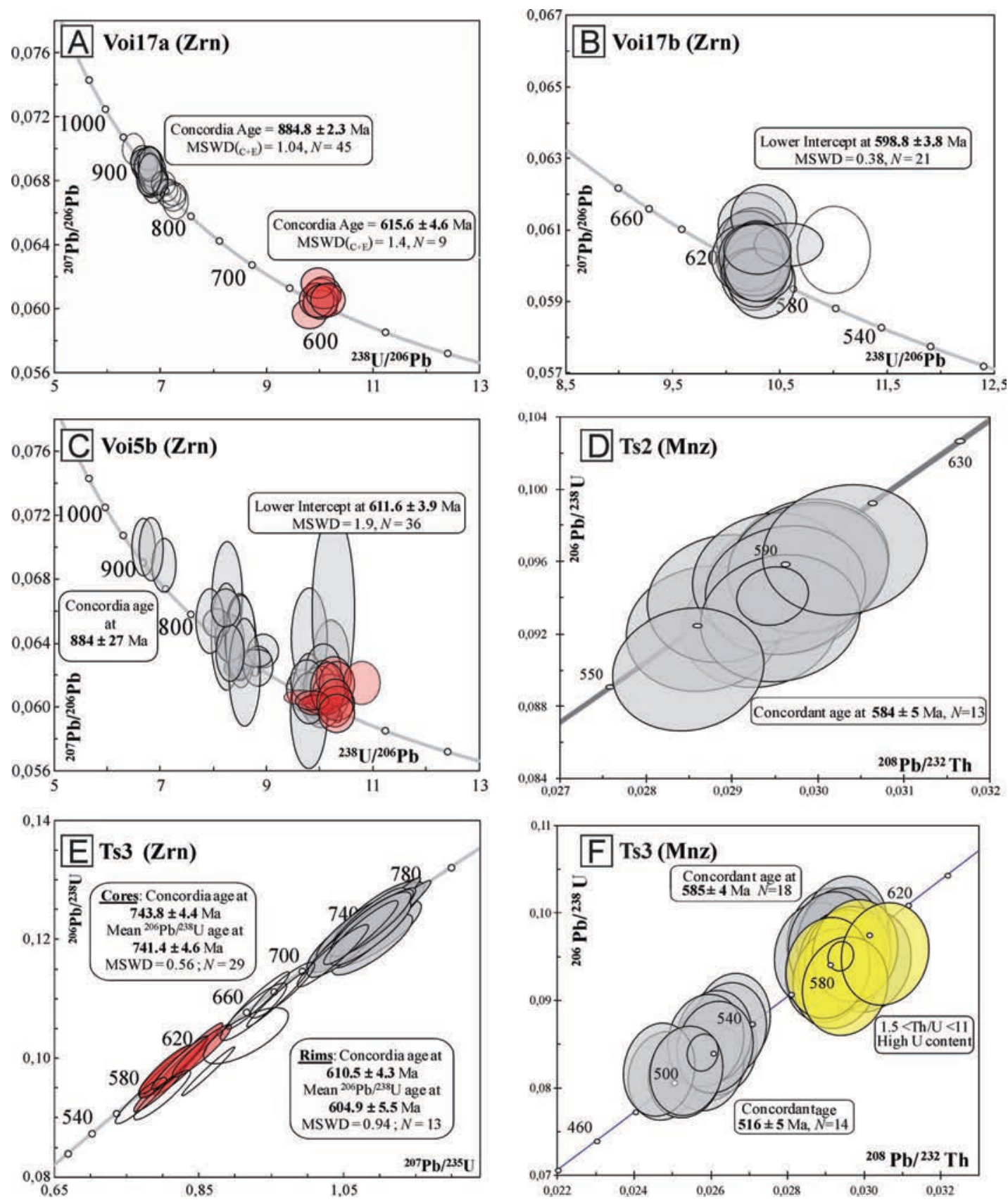

FIG. 4. Geochronological results obtained from zircon and monazite from the Kasigau Group. Data ellipses for each analysis are defined by standard $2 \sigma$ errors (Supplementary Table 1 ).

5 Ma. In most of the monazite, the Th content varies between 10,300 and $27,800 \mathrm{ppm}$ and the $\mathrm{U}$ content varies between 132 and $1280 \mathrm{ppm}(1.4<\mathrm{Th} / \mathrm{U}<149)$ with no clear correlation with the measured age. The
$\mathrm{Th} / \mathrm{U}$ values for the youngest samples measured are usually $\geq 24.5$ and contain among the lowest values of $\mathrm{U}(132<\mathrm{U}<930 \mathrm{ppm})$ compared to the monazite grains in other units. Some monazite domains which 


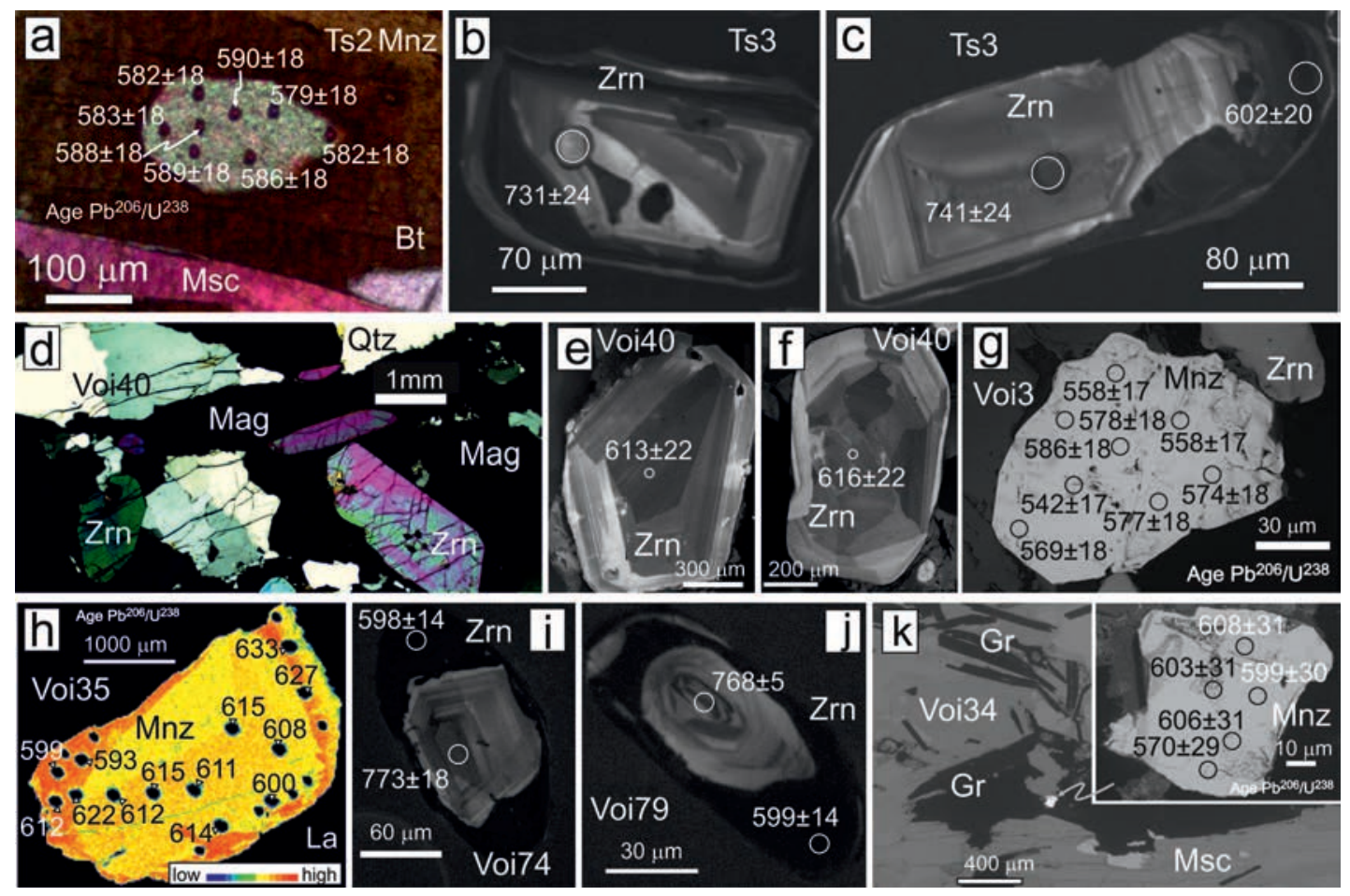

FIg. 5. Images showing representative texture of dated minerals (Zrn and Mnz). Ages are given in Ma. In the Kasigau Group: (a) monazite located inside a biotite crystal (sample Ts2); (b, c) cathodoluminescence images of zircon showing growth bands (sample Ts3). In the Kurase-HT gneisses: (d) large zircon inside a quartzo-feldspathic rock rich in magnetite observed with a cross-polarized microscope (sample Voi40); (e, f) corresponding cathodoluminescence images of euhedral zircon crystals displaying oscillatory zoning; (g) backscattered image showing a rounded monazite inside the matrix of a felsic granulite $\left(\mathrm{Pb}^{206} / \mathrm{U}^{238}\right.$ ages are indicated) (sample Voi3). In the Kurase-TB metasediments: (h) large monazite with La variation obtained from EPMA and localized $\mathrm{Pb}^{206} / \mathrm{U}^{238}$ ages $(2 \sigma$ error between 18 and 19 Ma) (sample Voi35); (i, j) cathodoluminescence zircon images from graphitic gneisses (samples Voi74, 79); (k) exceptional and small monazite from graphite-bearing gneiss (backscattered images, $\mathrm{Pb}^{206} / \mathrm{U}^{238}$ ages are indicated) (sample Voi34).

belong to the "585 Ma" group are enriched in Th (between 45,500 and 59,500 ppm) and, more surprisingly, are strongly enriched in U (up to $31,100 \mathrm{ppm}$ ), resulting in low $\mathrm{Th} / \mathrm{U}$ ratios (1.5 to 10.8 ).

\section{Kurase high-temperature gneisses}

The Voi39 pegmatite is characteristic of a differentiated felsic melt. Thirty-five spots on zircons resulted in a single concordia age of $606.5 \pm 3.0 \mathrm{Ma}$ (Fig. 6b; Supplementary Table 1), interpreted as the age of crystallization for this pegmatite.

Sample Voi40 is a leucosome with a slight fabric containing large (sometimes millimetric in length, Fig. $5 \mathrm{~d}-\mathrm{f}$ ) and euhedral zircon crystals, displaying an oscillatory or sector zoning. Twenty-eight spots yielded a concordia age of $616.7 \pm 3.7 \mathrm{Ma}$ (Fig. 6a; Supplementary Table 1), which is slightly older than sample Voi39.
Two large monazite grains, one in the quartzofeldspathic matrix, one in a garnet $(\sim 150 \mu \mathrm{m}$ in diameter, Fig. $5 \mathrm{~g}$ ), were analyzed in situ in the stromatic migmatite Voi3. Thirty-two analyses yielded a concordant Th-U-Pb age of $578 \pm 3$ Ma (Fig. 6c; Supplementary Table 2). The Th and $U$ contents vary from 8400 to $43,500 \mathrm{ppm}$ and from 640 to $2540 \mathrm{ppm}$, respectively, with no correlation with the measured age. The $\mathrm{Th} / \mathrm{U}$ ratios are between 4 and 60 .

The felsic granulite sample Voi2a contains rounded zircon with irregular zoning characteristic of metamorphic crystallization. Data plot around $610 \mathrm{Ma}$ (Fig. 6d; Supplementary Table 1), nevertheless, two timepopulations may be distinguished within analytical uncertainties. Thirty-six spots from crystal cores define a concordia age of $619.0 \pm 2.9 \mathrm{Ma}$, and 10 spots mainly located in the U-poor rims yield a concordia age of $599.1 \pm 7.4 \mathrm{Ma}$. 

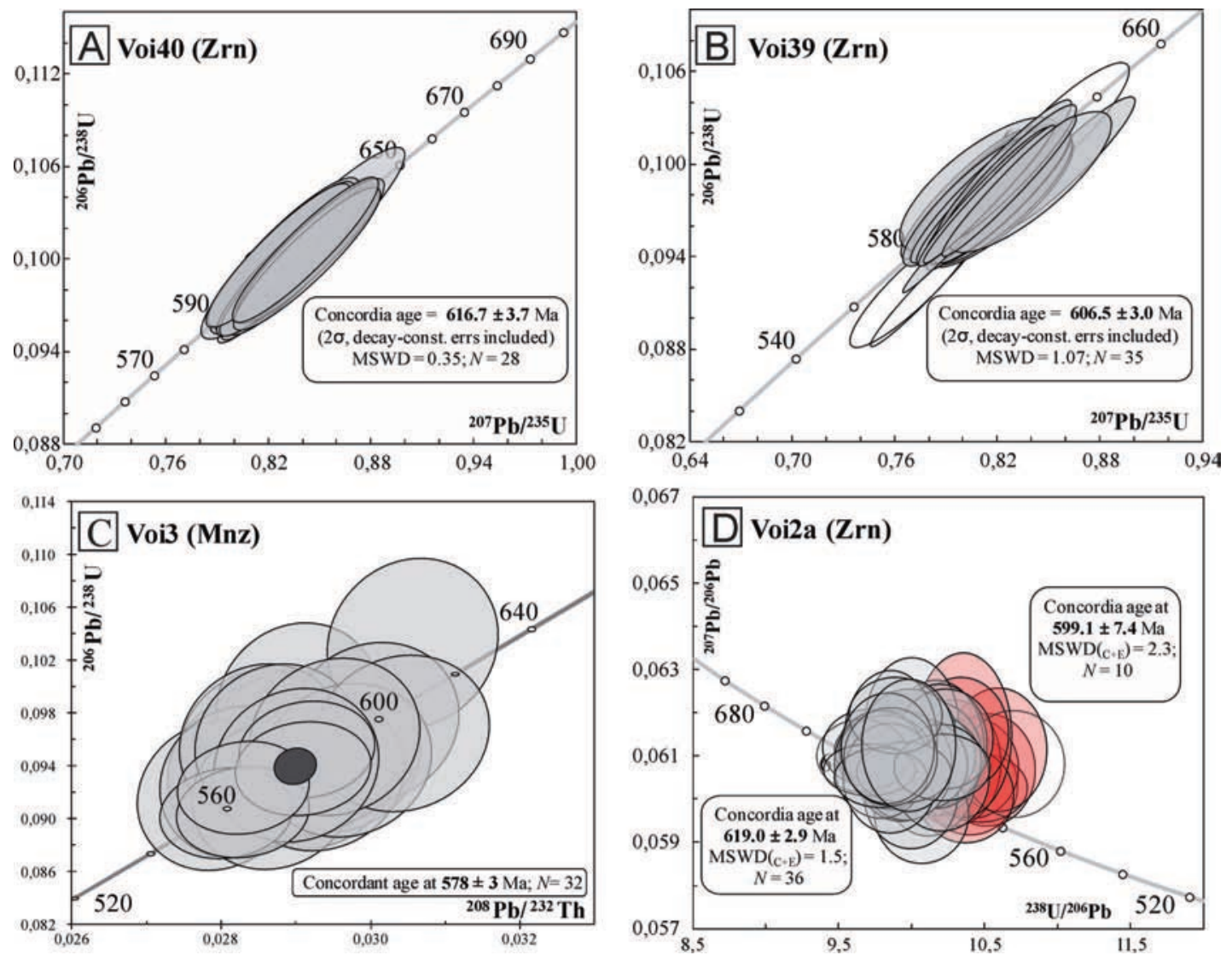

FIG. 6. Geochronological results obtained from zircons and monazites for samples (A) Voi40, (B) Voi39, (C) Voi3, and (D) Voi2a

(Kurase-HT gneisses). Data ellipses for each analysis are defined by standard $2 \sigma$ errors (Supplementary Tables 1 and 2 ).

\section{Kurase tsavorite-bearing metasediment}

In the slightly strained meta-rudite sample Voi35, two types of monazite grains have been found: large grains showing complex chemical zoning (up to 300 $\mu \mathrm{m}$ in length, Fig. 5h) and smaller grains around 70 $\mu \mathrm{m}$ in diameter. Two groups of ages are obtained; they do not correlate with the grain size (Fig. 7b; Supplementary Table 2). The older group yields a concordant Th-U-Pb age of $615 \pm 2 \mathrm{Ma}(n=27)$ and is characterized by a strong enrichment in $U$ (up to $45,870 \mathrm{ppm}$ ) and very low $\mathrm{Th} / \mathrm{U}$ ratios (between 0.5 and 3). The younger group consists of five ${ }^{208} \mathrm{~Pb} /{ }^{232} \mathrm{Th}$ ages scattered between $507 \pm 13$ and $553 \pm 14$ Ma. The $U$ contents in these monazite domains are lower than in the older monazites $(1700<\mathrm{U}<7700 \mathrm{ppm})$ and the $\mathrm{Th} / \mathrm{U}$ ratios are between 5 and 20 .

The meta-rudite samples Voi28 and Voi29 contain rare yellow zircon crystals which are cloudy with numerous cracks. They are often highly U-enriched (up to $6000 \mathrm{ppm} \mathrm{U}$ ), and consequently mostly metamict, and often contain significant amounts of common $\mathrm{Pb}$. Only the analyses of the best-preserved crystals were selected and they define two similar concordia ages of $603.4 \pm 4.5 \mathrm{Ma}$ and $606.7 \pm 5.8$ Ma for samples Voi28 and 29, respectively (Fig. 7c, d; Supplementary Table 1). These are maximum ages because a weak contribution of common $\mathrm{Pb}$ remains possible. Four monazite grains separated from sample Voi28 were analyzed. Thirty-two analyses yield a concordant $\mathrm{Th}-\mathrm{U}-\mathrm{Pb}$ age of $596 \pm 2 \mathrm{Ma}$ (Fig. 7e; Supplementary Table 2). In this sample the Th and $\mathrm{U}$ contents vary from 19,800 to $53,200 \mathrm{ppm}$ and from 1660 to $8040 \mathrm{ppm}$, respectively. The $\mathrm{Th} / \mathrm{U}$ ratios are between 4 and 14 .

In the graphitic gneisses, zircon crystals are rare compared to the other rocks. In the three samples, the oldest measured ages scatter between 650 and $850 \mathrm{Ma}$ (Fig. 7f, g; Supplementary Table 1). Ten spots from 

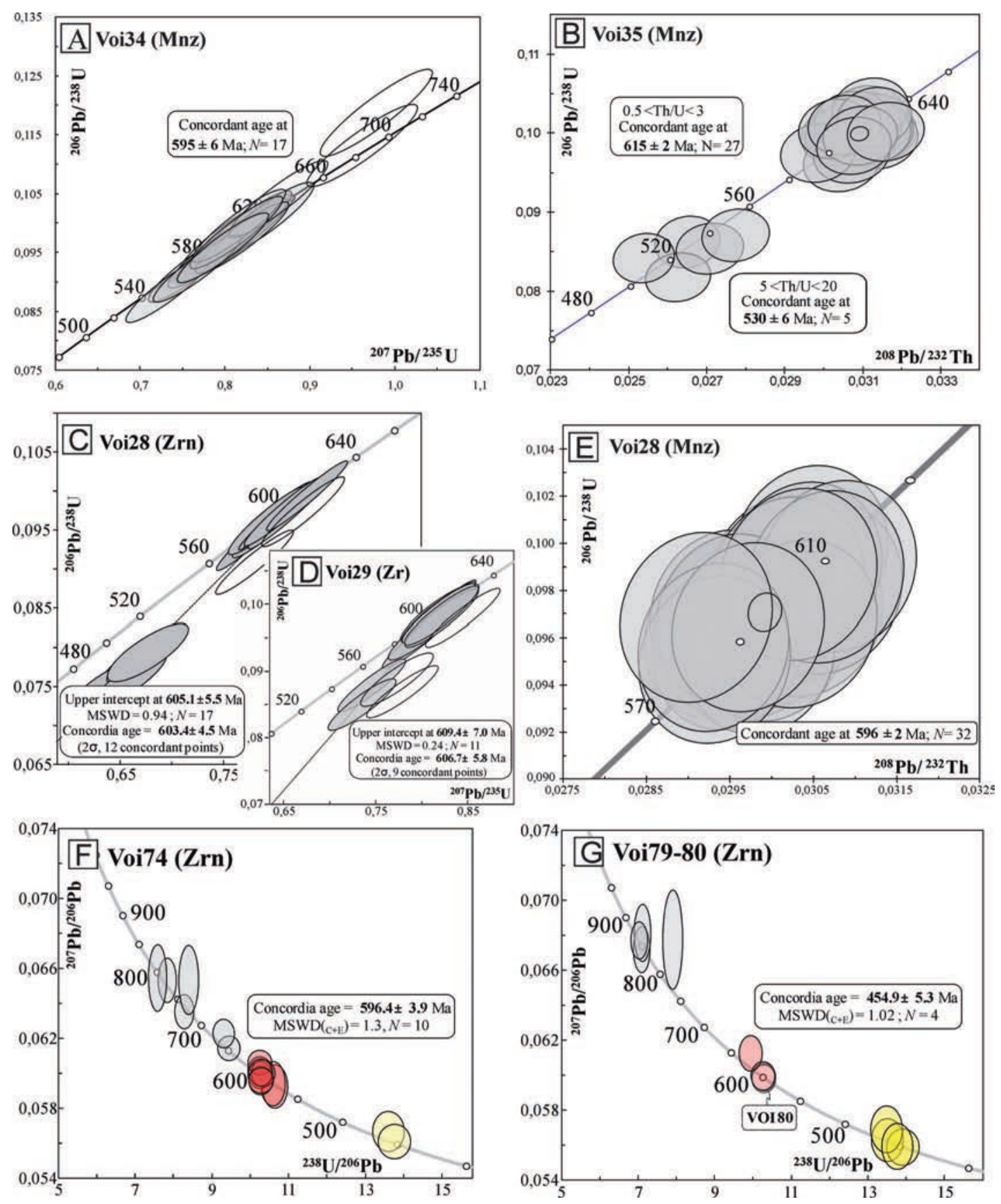

FIG. 7. Geochronological results obtained from zircon and monazite from Kurase-TB metasediments. Data ellipses for each analysis are defined by standard $2 \sigma$ errors (Supplementary Tables 1 and 2).

graphitic gneiss Voi74 yielded a concordia age of $596.4 \pm 3.9 \mathrm{Ma}$ (Fig. 7f), which is in agreement with individual spot analyses obtained from samples Voi79-Voi80 (Fig. 7g). All these analyses plotting at
$600 \mathrm{Ma}$ correspond to rims displaying high $\mathrm{U}(>800$ $\mathrm{ppm})$ content and a low $\mathrm{Th} / \mathrm{U}$ ratio $(<0.05$, Fig. $5 \mathrm{i}, \mathrm{j})$. Finally, in samples Voi74 and Voi79, a few spots yielded unusually young ages of around $450 \mathrm{Ma}$ (Fig. 

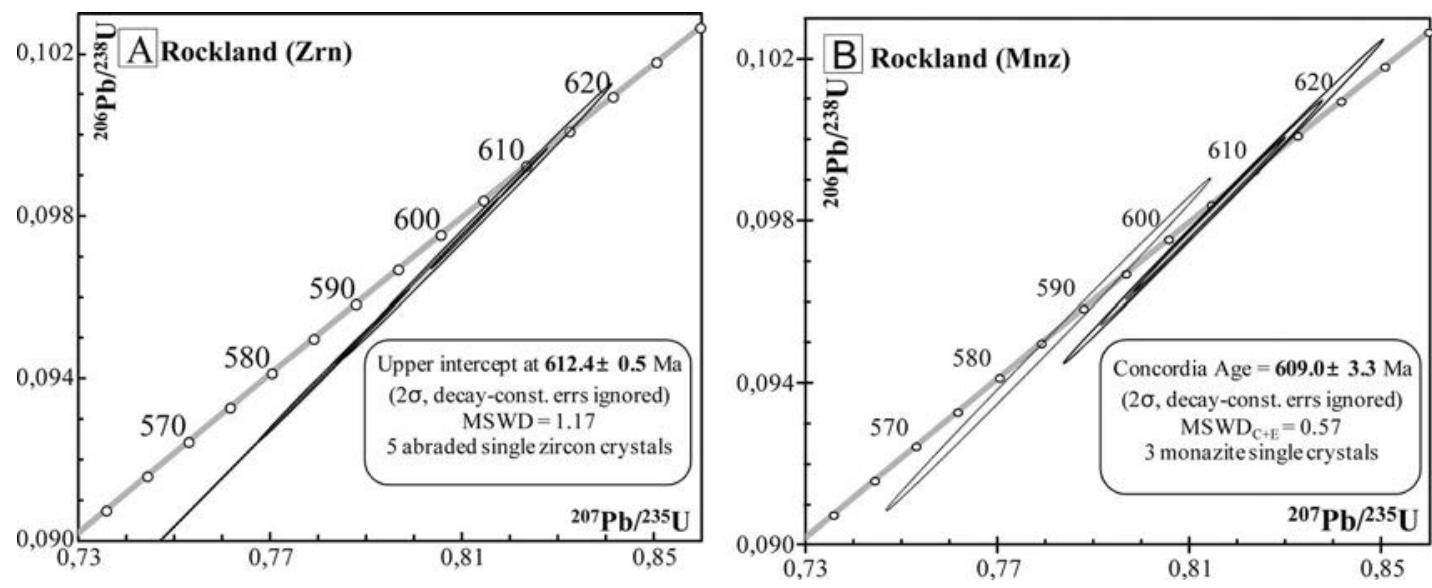

FIG. 8. Geochronological results obtained from separated zircon and monazite from ruby-bearing plumasite (Rockland, Kimbo pit, Kurase-TB metasediments; Supplementary Table 3).

$7 f$, g). Like zircon, monazite is very rare in the graphitic gneiss. Only sample Voi34 provided a few small elongated or rounded monazite grains (three, $20-150 \mu \mathrm{m}$ in length, Fig. $5 \mathrm{k}$ ). The Th-U-Pb data are scattered between 737 and 547 Ma (Fig. 7a). Considering that the older ages (between 747 and $660 \mathrm{Ma})$ can be attributed to inheritance, a concordant $\mathrm{U}-\mathrm{Pb}$ age was calculated at $595 \pm 6 \mathrm{Ma}(n=17)$, in agreement with the weighted average ${ }^{208} \mathrm{~Pb} /{ }^{232} \mathrm{Th}$ age of $597 \pm 11 \mathrm{Ma}(\mathrm{MSWD}=5.2)$.

The desilicated pegmatites from the Kimbo pit in the Rockland mine provided U-rich zircon (3700 ppm). Five zircon crystals were analyzed by ID-TIMS, and they show upper intercepts of $612.4 \pm 0.5 \mathrm{Ma}$ (Fig. 8a; Supplementary Table 3). The ${ }^{208} \mathrm{~Pb} /{ }^{206} \mathrm{~Pb}$ ratio can be considered as a proxy of the $\mathrm{Th} / \mathrm{U}$ ratio and provides very low values, below 0.01 . Finally, samples from the Kimbo pit provided three euhedral abraded monazite crystals. Analyses performed with an ID-TIMS indicate upper intercepts at $609.0 \pm 3.3$ Ma (Fig. 8b; Supplementary Table 3).

\section{$\mathrm{U}-\mathrm{Pb}$ rutile geochronology}

Rutile grains from two graphitic gneisses (Voi79 and Voi80) were dated. Nineteen spots were analyzed in each sample and yield a concordia age of $515.2 \pm$ 4.1 $\mathrm{Ma}$ and a lower intercept age of $515.2 \pm 6.2 \mathrm{Ma}$ for Voi79 and Voi80, respectively (Fig. 9a, b; Supplementary Table 1).
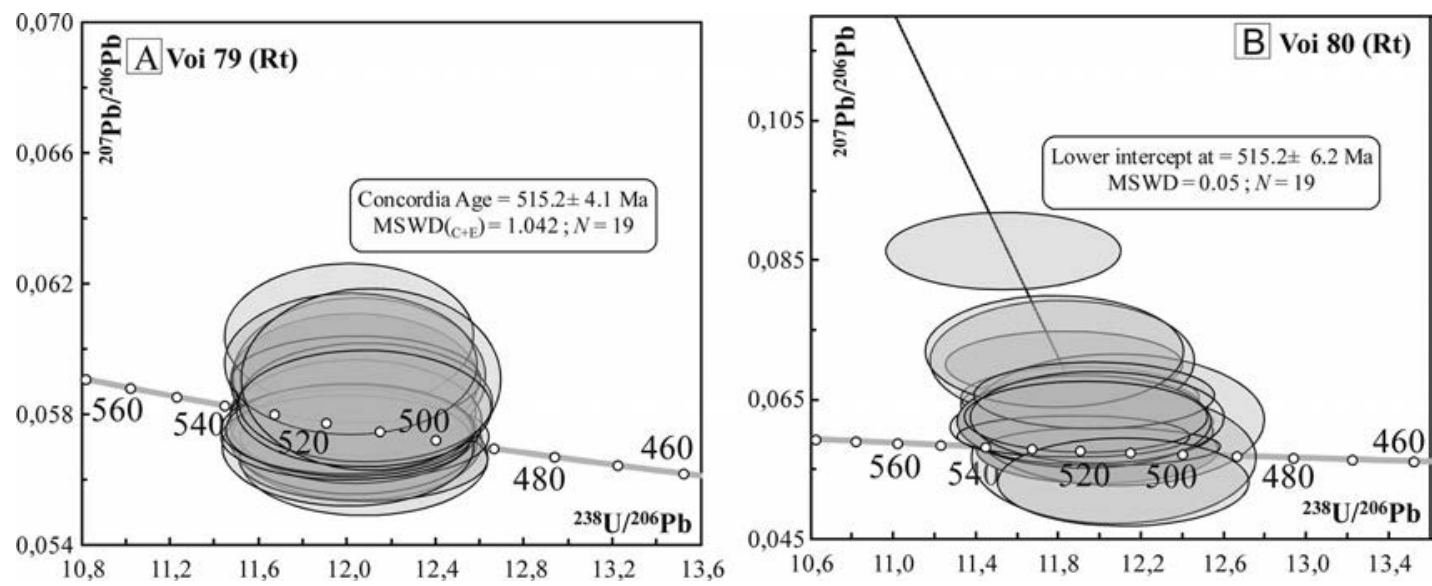

FIG. 9. ${ }^{207} \mathrm{~Pb} /{ }^{206} \mathrm{~Pb}$ versus ${ }^{238} \mathrm{U} /{ }^{206} \mathrm{~Pb}$ diagram for rutile geochronology (samples Voi79 and Voi80 in the Kurase-TB metasediments, Supplementary Table 1). 

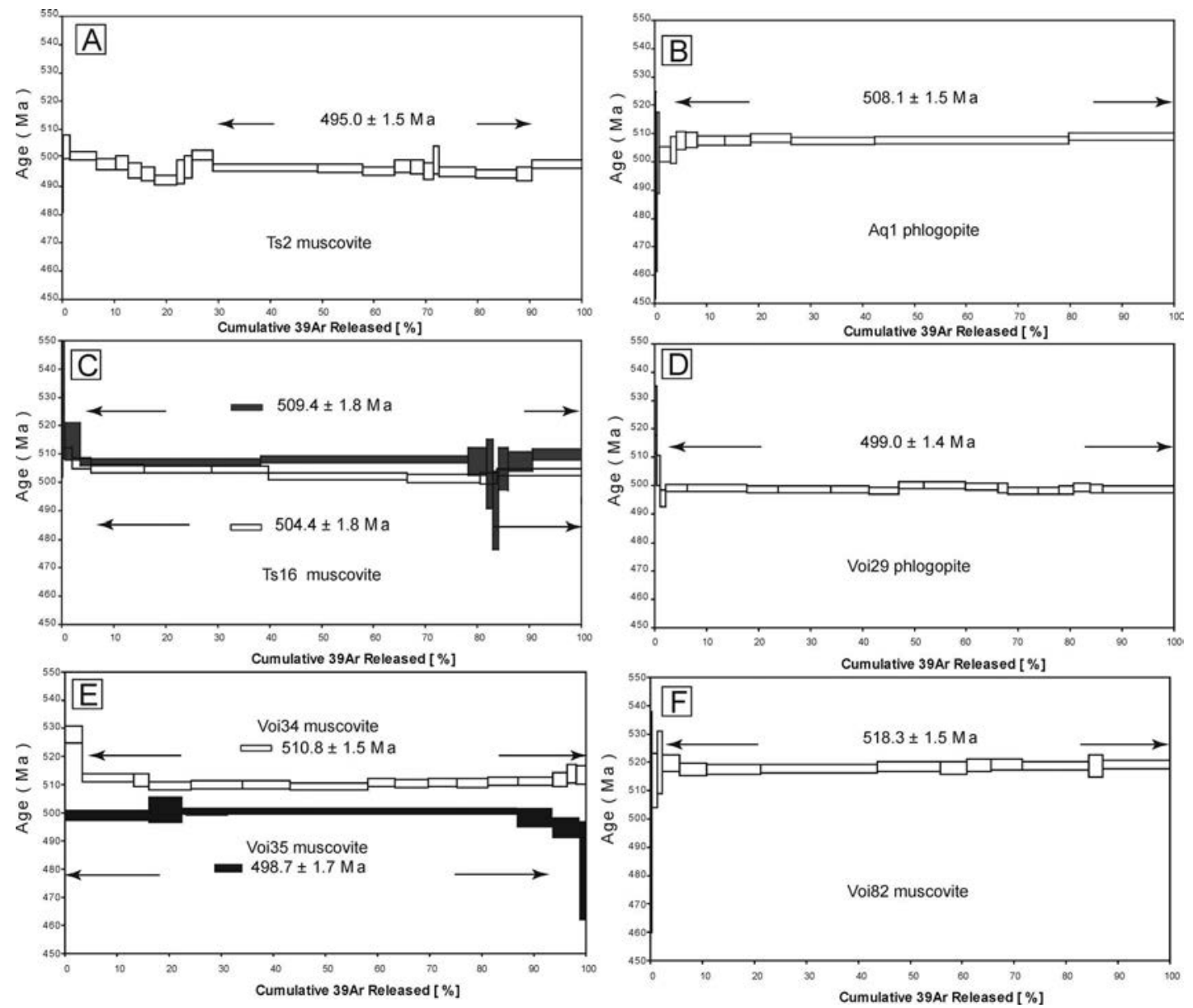

FIG. 10. Results from argon geochronology. Single-grain ${ }^{40} \mathrm{Ar} /{ }^{39} \mathrm{Ar}$ laser step-heating profiles (all sample outcrops in Kurase-TB metasediments except Ts3 comes from the Kasigau Group). Age error bars for each temperature step are in $1 \sigma$. Chemistry of minerals is given in Table 1; analyses for argon are given in Supplementary Table 4.

\section{Argon Geochronological Results}

Phlogopite and muscovite grains selected for dating are mainly representative of the Kurase-TB metasediments, but one sample comes from the Kasigau Group (Fig. 2). Results from single grains of muscovite and phlogopite (Table 1) are discussed together, as they are considered, for this specific chemistry, to record the same Ar-cooling temperature (around $430{ }^{\circ} \mathrm{C}$, Harrison et al. 2009). Taken together, all phyllosilicates display high precision plateau ages for at least $65 \%$ of the ${ }^{39} \mathrm{Ar}$ released (Fig. 10; Supplementary Table 4). For two samples (Ts16 and Voi35), age determinations of two muscovite grains are relatively consistent with the flat portion of the spectra, yielding plateau ages between $509.4 \pm 1.8 \mathrm{Ma}$ and $504.4 \pm 1.8 \mathrm{Ma}$ for Ts16 (Fig. 10c) and between $498.7 \pm 1.7 \mathrm{Ma}$ and $504.4 \pm 1.8$
Ma for Voi35, which indicates a homogeneous isotopic composition of these micas for argon. Considering all the results, the obtained ages vary from $518.3 \pm 1.5$ to $495.0 \pm 1.5 \mathrm{Ma}$. The ages from phlogopite (sample Voi29 and Aq1) are similar to the ones measured in muscovite. Micas from the rock matrix show lobed grain limits (Voi29, $499.0 \pm 1.4$ Ma) and display ages similar to the late crystallized ones with nicely euhedral shapes taken from dilatant structures (Aq1, 508.1 $\pm 1.5 \mathrm{Ma})$. Samples Voi34 and Voi82 correspond to the graphitic gneiss hosting the productive nodule and the V-rich muscovite (Table 1). They display ages consistent with the other rocks. The ages are slightly higher in sample Voi82, where the grains are large (centimetric) with gem-quality kyanite (518.3 \pm 1.5 Ma, Figs. $3 g, 10 f)$. The sample from 


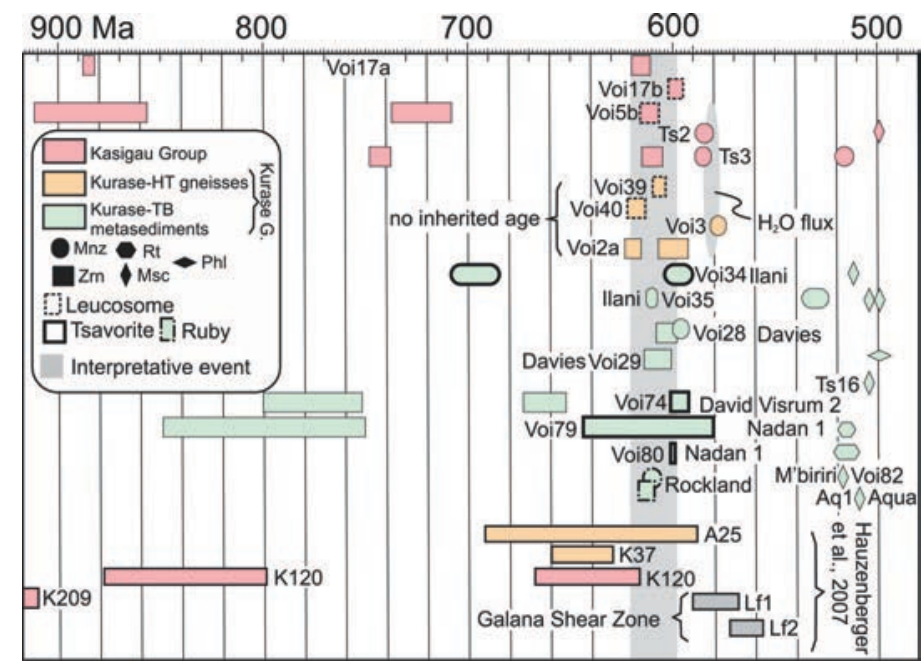

FIG. 11. Summary of geochronological data from southeastern Kenya, see text and Figures 4, 6-10 for explanations.

Kasigau (Ts2) contains muscovite yielding the youngest age (Fig. 10a). The first third of the age spectrum measured provides scattered ages, with a saddleshaped pattern. However, a plateau age of $495.0 \pm$ $1.5 \mathrm{Ma}$ can be calculated for $60 \%$ of the ${ }^{39} \mathrm{Ar}$ released.

Thus we consider that the results are quite homogeneous and that all samples recorded a common history of cooling below $430{ }^{\circ} \mathrm{C}$ which occurred between 510 and $500 \mathrm{Ma}$. This is compatible with U$\mathrm{Pb}$ results obtained for rutile from samples Voi79 and 80. The slight spread of ages from 495.0 to $518.3 \mathrm{Ma}$ can be explained by different crystal sizes (sample Voi82) acting on argon retentivity and by weak argon loss associated with weathering (Ts2).

\section{Linking Late Neoproterozoic Events to MetAMORPHISM}

Ages measured from zircon and monazite display a statistically dominant group (Fig. 11) corresponding to late Neoproterozoic ages ranging from 620 to $585 \mathrm{Ma}$. We discuss below their relationship with regional tectonometamorphic events undergone by the Kasigau Group, the Kurase-HT gneisses, and the Kurase-TB metasediments.

\section{Kasigau Group}

In the Kasigau Group, zircon from high-grade migmatites shows metamorphic rims dated at $615.6 \pm$ 4.6 Ma (Voi17a) and $610.5 \pm 4.3 \mathrm{Ma}$ (Ts3). These are synchronous with the crystallization ages of the segregated leucosomes $(611.6 \pm 3.8 \mathrm{Ma}$, Voi5b). This suggests that this age corresponds to the peak conditions of the metamorphic event in the granulite facies $\left(820^{\circ} \mathrm{C}, 11-12 \mathrm{kbar}\right.$, Hauzenberger et al. 2004). These results are in agreement with previous studies (665-615 Ma, Hauzenberger et al. 2007). The crystallization age of a felsic dike (Voi17b), crosscutting the high-grade migmatite (Voi17a), is younger $(598.8 \pm 3.8 \mathrm{Ma})$. In Ts2, clear retrogression in the amphibolite facies is shown by the crystallization of large millimetric muscovite grains from sillimanite cutting across the foliation planes. The associated monazite crystals record a single age of $584 \pm 5 \mathrm{Ma}$ that is interpreted to be the age of the retrogression in the amphibolite facies associated with water influx. This is also supported by monazites in sample Ts 3 that provided very similar results (18 spots displaying ages of $585 \pm 4 \mathrm{Ma}$ ). Sample Ts3 also contains fractured and U-poor monazites which give younger ages of 516 $\mathrm{Ma} \pm 5 \mathrm{Ma}(14$ spots $)$ and are not related to any mineral overprint.

\section{Kurase high-temperature gneisses}

To constrain the granulite facies event in the Kurase-HT gneisses, we selected rocks with clear evidence of fluid-absent biotite melting (Voi2a, Voi3) in addition to pegmatite rocks and segregated leucosomes close to the felsic charnockites (Voi39, Voi40). Zircon dating provided a crystallization age of pegmatite sample Voi39 of $606.5 \pm 3.0 \mathrm{Ma}$ and of the leucosome in sample Voi40 of $616.7 \pm 3.7 \mathrm{Ma}$. Metamorphic zircons from the felsic granulite Voi2a display two age populations: one at $619.0 \pm 2.9 \mathrm{Ma}$ (36 spots in zircon cores) and the other at $599.1 \pm 7.4$ $\mathrm{Ma}$ (10 spots in rim). This suggests that the granulite- 
facies event $\left(820{ }^{\circ} \mathrm{C} 11-12 \mathrm{kbar}\right.$, Hauzenberger et al. 2004) occurred at the same time as continuous pulses of magma between 620 and $600 \mathrm{Ma}$. These ages are slightly younger than those obtained for the same lithology northward (Figs. 2, 11; sample K37, 660 to $630 \mathrm{Ma}$, Hauzenberger et al. 2007). Monazite grains from the similar felsic granulite Voi3 recorded different ages, even when located inside the garnet produced by dehydration melting of biotite. The 32 analyses yield a concordant Th-U-Pb age of $578 \pm 3$ $\mathrm{Ma}$, compatible with the occurrence of small muscovite grains in late fractures. This age is similar to the one associated with clear retrogression in the amphibolite facies conditions in the Kasigau Group (monazite from Ts2 and Ts3). As monazite crystallization is highly sensitive to fluid circulation, those ages may be related to volatile migration along garnet fractures during retrogression.

\section{Kurase tsavorite-bearing metasediments}

Samples Voi34 and 35 come from the northern part of Mgama Ridge. The slightly strained meta-rudite sample (Voi35) bears large U-rich monazites that provided one group of ages at $615 \pm 2 \mathrm{Ma}(n=27)$. As the monazites are found in the same layers as the centimetric muscovites, it suggests that the $615 \mathrm{Ma}$ age reflects amphibolite-facies conditions. Four ${ }^{208} \mathrm{~Pb} /{ }^{232} \mathrm{Th}$ ages scattered between $553 \pm 14$ and $507 \pm 13 \mathrm{Ma}$ are similar to the young age measured from sample Ts3 of $516 \pm 5 \mathrm{Ma}$. The graphitic gneisses (Voi34) containing tsavorite (Ilani mining sector) display rare small monazites that yielded concordant $\mathrm{U}-\mathrm{Pb}$ ages of $595 \pm 6 \mathrm{Ma}(n=17)$. This sample contains nodules of sillimanite with muscovite, which suggests that amphibolite-facies conditions persisted at $595 \pm 6 \mathrm{Ma}$.

In the Davies mine, unstrained monazites from the meta-rudite Voi28 returned a calculated concordant Th-U-Pb age of $596 \pm 2 \mathrm{Ma}$, consistent with those obtained for separated zircons from the same sample $(603.4 \pm 4.5 \mathrm{Ma})$ and from sample Voi29 (606.7 \pm $5.8 \mathrm{Ma})$. Samples Voi28 and Voi29 contain large muscovites and thus underwent metamorphism under amphibolite-facies conditions at $605 \mathrm{Ma}$.

Like the other graphitic gneisses, samples Voi74 (David Visrum 2 mine) and Voi79 and Voi80 (Nadan 1 mine) contain rare zircons. The samples are devoid of muscovite and contain sillimanite without other phases symptomatic of granulite-facies metamorphism. In sample Voi74, a concordia age of $596.4 \pm$ 3.9 Ma was found, in agreement with analyses of the rims of samples Voi79 and Voi80 which display ages of $\sim 600 \mathrm{Ma}$. These samples also underwent metamorphism in the amphibolite facies at $\sim 600 \mathrm{Ma}$.
Ages of the ruby-bearing plumasites (Rockland mine) are interesting in two ways: first, they are associated with a rare example of metasomatism associated with gem formation, and second, the desilication occurred under local granulite-facies conditions $\left(T=700-750{ }^{\circ} \mathrm{C}\right.$ and $P=8-10.5 \mathrm{kbar}$, Mercier et al. 1999). In this case, separated zircon and monazite crystals display similar results with ages of $612.4 \pm 0.5$ and $609.0 \pm 3.3 \mathrm{Ma}$, respectively, attesting to their synchronous crystallization.

\section{Discussion AND Conclusions}

\section{Tonien inheritance}

Ages older than $700 \mathrm{Ma}$ are recorded in some zircon cores and rarely in monazites (Voi34) from the Kasigau Group and the Kurase-TB metasediments and not from the Kurase-HT gneisses. These ages are in agreement with those obtained from neighboring rocks (Hauzenberger et al. 2007). In this study, all the rocks belong to the Eastern Granulite Belt and display inherited ages older than $700 \mathrm{Ma}$, usually interpreted as emplacement ages of the magmatic rocks (850-950 Ma) with no record of Archean or Paleoproterozoic events (Hauzenberger et al. 2007, Fritz et al. 2009, 2013, Tenczer et al. 2013).

\section{Late Neoproterozoic metamorphic events}

In the regional frame of the East African Orogen, granulite-facies metamorphism was associated with hot nappes stacking in the interval $640-620 \mathrm{Ma}$ (Tenczer et al. 2013). The younger ages reported in these studies are in agreement with the $620-615 \mathrm{Ma}$ ages obtained in the present study. The absence of ages between 630 and $645 \mathrm{Ma}$ in our samples may illustrate the regional east-west diachronism of the granulitefacies metamorphism in the belt (Tenczer et al. 2013). It could also be the result of heterogeneous finite strain as demonstrated to the west, in the Lossogonoï district, where newly formed metamorphic zircons in a vertical shear zone formed under amphibolite-facies conditions at $610 \mathrm{Ma}$ and postdate the Pan-African metamorphic peak at 640-620 Ma (Le Goff et al. 2010).

Monazites from the migmatites in the Kasigau Group and Kurase-HT gneisses yield concordant U$\mathrm{Th}-\mathrm{Pb}$ ages of about $580 \mathrm{Ma}$ (samples Ts2, Ts3, Voi3). These ages only recorded in monazites are comparable with the one obtained eastward in the Galana vertical shear zone where they are associated with granulitefacies metamorphism (Hauzenberger et al. 2007) or magmatic dike emplacement to the north (Simonet et al. 2004). This $580 \mathrm{Ma}$ event is linked to the final amalgamation of micro-continents forming Gondwana (Kuunga orogeny, Meert 2003). Thus we consider that 
shearing along the large Galana Shear zone and the emplacement of magmatic dikes are associated with local to more pervasive fluid mobility in neighboring terrains, controlling monazite crystallization at 585 Ma.

\section{Synchronous metamorphism of Kasigau and Kurase Groups}

As shown by Hauzenberger et al. (2004, 2007), our results show that the Kasigau and Kurase-HT gneisses (Taita Hills) synchronously underwent metamorphism at the same peak conditions with abundant partial melting. In the Kurase Group, the Kurase-TB metasediments escaped partial melting and were preserved from deformation. Moreover, sedimentary structures were preserved. These rocks were metamorphosed at lower grade than the Kurase-HT gneisses, under amphibolite-facies conditions, and in a very static regime. Ages close to $615 \mathrm{Ma}$ are only recorded in sample Voi35, which is strained, and at Rockland, where local metasomatism and higher metamorphism occurred (granulite-facies conditions, Mercier et al. 1999). Our results show that these three units, Kasigau Group, Kurase-HT gneisses, and Kurase-TB metasediments, were metamorphosed at the same time (620 to $600 \mathrm{Ma})$, but under different $P-T$ and strain conditions.

\section{Timing of tsavorite crystallization}

No U-rich minerals have been found in the tsavorite nodules. In our area, the samples found closest to tsavorite nodules of gem quality are the Voi34, Voi74, Voi79, and Voi80 samples. These samples contain rare monazite and zircon that crystallized synchronously at around $600 \mathrm{Ma}$. This is the youngest part of the amphibolites-facies metamorphism recorded in the Kurase-TB metasediments from 615 to $600 \mathrm{Ma}$. Tsavorite formed in nodules, the largest $10 \mathrm{~cm}$ in diameter, that were statically heated during prograde metamorphism up to $7 \mathrm{kbar}$ and 680 ${ }^{\circ} \mathrm{C}$ (Feneyrol et al. 2012, 2017, Giuliani et al. 2014). Thus tsavorite grew during isochemical metamorphism by the transfer of elements over more than 10 $\mathrm{cm}$. Taking into account the size of the nodules and the lack of strain, we suggest that the tsavorite formation is related to a slow mechanism that may have been completed at the end of the prograde metamorphism at around $600 \mathrm{Ma}$ when the temperature and the amount of volatiles were at their highest.

\section{Paleozoic event}

In the Kurase Group, ages close to $516 \mathrm{Ma}$ are recorded only in separated, U-depleted monazite crystals (Ts3). Other isolated spots give young dates of $530 \pm 6 \mathrm{Ma}(n=5$, Voi35). These dates may be related to more isolated events due to local tectonic structures. Such ages have been associated with the latest events affecting Gondwana, e.g., in zirconbearing calcite veins (Paquette et al. 1994). These ages at around $516 \mathrm{Ma}$ are close to the ${ }^{40} \mathrm{Ar} /{ }^{39} \mathrm{Ar}$ ages of $510-500 \mathrm{Ma}$ and to the rutile ages of 520-495 Ma. In the Aqua mine two rutiles included in corundum (ruby and pink sapphire) display compatible U-Pb ages of $533 \pm 11$ and $526 \pm 13 \mathrm{Ma}$ (in situ ICP-MS dating, Sorokina et al. 2017). ${ }^{40} \mathrm{Ar} /{ }^{39} \mathrm{Ar}$ ages have been obtained from muscovite and biotite from the same area (Bauernhofer et al. 2009). Their interpretation is not straightforward due to inherited argon in some samples. Nevertheless, an unfoliated pegmatite from the Taita Hills yielded an age of $505 \mathrm{Ma}$ and two wellfoliated mafic migmatites from the Galana shear zone display plateau ages of 500 and $490 \mathrm{Ma}$. Moreover, in this part of the Mozambican belt, Feneyrol (2012) reported similar ${ }^{40} \mathrm{Ar} /{ }^{39} \mathrm{Ar}$ results of 516-492 Ma for a marble and two graphitic gneisses from Meralani, Lemshucu, and Namalulu. Möller et al. (2000) dated several samples and especially rutile crystals from two metapelites from the Kurase Group (samples A108 and A144) displaying ${ }^{206} \mathrm{~Pb} /{ }^{238} \mathrm{U}$ ages of around $529-510$ $\mathrm{Ma}$, consistent with our $\mathrm{U}-\mathrm{Pb}$ ages in rutile. Elementdiffusion estimates from garnet-biotite profiles in samples from the Kurase Group (Taita Hills) suggest a slow cooling rate of about $3-5^{\circ} \mathrm{C} / \mathrm{my}$ (Hauzenberger et al. 2005). Data converge to a cooling below $430{ }^{\circ} \mathrm{C}$ at a regional scale at $510-500 \mathrm{Ma}$. This is compatible with a slow cooling rate $\left(T<5{ }^{\circ} \mathrm{C} / \mathrm{my}\right)$, operating over a large area, indicative of large-scale geological processes, such as isostatic readjustment, instead of fast tectonic processes.

\section{ACKNOWLEDGMENTS}

The work on tsavorite was supported by the Institut de Recherche pour le Développement (IRD, France) and the French CNRS (CRPG/CNRS, GET/IRD, LGL) in collaboration with the University of Nairobi (Kenya). The authors thank GET/IRD, CRPG/CNRS, the CESSUR-INSU program (2009-2011), and SCAC from the French Embassy in Nairobi (Kenya) for financial support. We thank the mine managers and miners for allowing access to their quarries and pit in a friendly manner. Bertrand Van De Moortèle and JeanLuc Devidal are also thanked for their help with the SEM and EPMA, respectively. The corrections and suggestions of Prof. Lee Groat, Editor of The Canadian Mineralogist, and Prof. Dan Marshall, Guest Editor, as well as the comments of reviewers Dr. Elisabeth Le Goff and Dr. Christopher Hauzenberger, were greatly appreciated. 


\section{ReFERENCES}

Bauernhofer, A.H., Hauzenberger, C.A., Wallbrecher, E., Hoinkes, G., Muhongo, S., \& Mathu, E.M. (2008) Panafrican deformation in SE Kenya and NE Tanzania: geotectonic implications for the development of the northcentral Mozambique belt. African Journal of Science and Technology, Science and Engineering Series 9, 50-71.

Bauernhofer, A.H., Hauzenberger, C.A., Handler, R., Wallbrecher, E., Hoinkes, G., Muhongo, S., \& Mathu, E.M. (2009) ${ }^{40} \mathrm{Ar} /{ }^{39} \mathrm{Ar}$ cooling ages of Pan-african structures from the Mozambique belt in SE Kenya: implications for the cooling history. African Journal of Science and Technology, Science and Engineering Series 10, 1-1.

Burke, K. \& Dewey, J.F. (1972) Orogeny in Africa. In African Geology (T.F.J. Dessauvagie \& A.J. Whiteman, eds.). Department of Geology, University of Ibadan (583608).

Collins, A.S. \& Pisarevsky, S.A. (2005) Amalgamating eastern Gondwana: The evolution of the Circum-India Orogens. Earth Science Reviews 71, 229-270.

Corfu, F. (1988) Differential response of U-Pb systems in coexisting accessory minerals, Winnipeg River Subprovince, Canadian Shield: implications for Archean crustal growth and stabilization. Contributions to Mineralogy and Petrology 98, 312-325.

DidiER, A. (2013) Comportement géochimique du chronomètre $\mathrm{U}-\mathrm{Th}-\mathrm{Pb}$ dans la monazite : approche par analyses in-situ au LA-ICP-MS. Sciences de la Terre. Université Blaise Pascal - Clermont-Ferrand II, Français, https://tel.archives-ouvertes.fr/tel-00966588.

Didier, A., Bosse, V., Boulvais, P., Bouloton, J., Paquette, J.-L., Montel, J.-M., \& Devidal, J.-L. (2013) Disturbance versus preservation of $\mathrm{U}-\mathrm{Th}-\mathrm{Pb}$ ages in monazite during fluid-rock interaction: textural, chemical and isotopic in situ study in microgranites (Velay Dome, France). Contributions to Mineralogy and Petrology 165, 10511072 .

Dissanayake, C.B. \& ChandrajtTh, R. (1999) Sri LankaMadagascar Gondwana Linkage: Evidence for a PanAfrican Mineral Belt. Journal of Geology 107, 223-235.

Feneyrol, J. (2012) Pétrologie, géochimie et genèse des gisements de tsavorite associés aux gneiss et roches calco-silicatées graphiteux de Lemshuku et Namalulu, Tanzanie. Ph.D., Université de Lorraine, Vandœuvre-lèsNancy, 620 p., http://docnum.univ-lorraine.fr/public/ DDOC_T_2012_0348_FENEYROL.pdf.

Feneyrol, J., Giuliani, G., Ohnenstetter, D., Le Goff, E., Malissa, E.P.J., SAul, M., SAul, E., SAul, J.M., \& Pardieu, V. (2010) Lithostratigraphic and structural controls of 'tsavorite' deposits at Lemshuku, Merelani area, Tanzania. Comptes Rendus Geoscience 342, 778785 .
Feneyrol, J., Monié, P., Giuliani, G., Ohnenstetter, D., \& MalisA, E. (2011) Panafrican ${ }^{39} \mathrm{Ar} /{ }^{40} \mathrm{Ar}$ ages $(520-505$ $\mathrm{Ma})$ of the tsavorite deposits in the Lelatema Fold Belt (northeastern Tanzania). Abstract CD-Rom European Geosciences Union General Assembly, Vienna, Austria.

Feneyrol, J., Ohnenstetter, D., Giuliani, G., Fallick, A.E., Rollion-Bard, Cl., Robert, J.-L., \& Malisa, E. (2012) Evidence of evaporites in the genesis of the vanadian grossular 'tsavorite' deposit in Namalulu, Tanzania. Canadian Mineralogist 50, 745-769.

Feneyrol, J., Giuliani, G., Ohnenstetter, D., Fallick, A.E., Martelat, J.-E., Monié, P., Dubessy, C., Rollion-Bard, Cl., Le Goff, E., Malisa, E., RaKotondrazafy, A.F.M., Pardieu, V., Kahn, T., Ichang'i, D., Venance, E., Voarintsoa, N.R., Ranatsenho, M., Simonet, C., Omito, E., Nyamai, C., \& SAUL, M. (2013) Worldwide tsavorite deposits: new aspects and perspectives. Ore Geology Reviews 53, 1-25.

Feneyrol, J., Giuliani, G., Demaiffe, D., Ohnenstetter, D., Fallick, A.E., Dubessy, J., Martelat, J.-E., Rakotondrazafy, A.F.M., Omito, E., Ichang'i, D., Nyamai, C., \& Wamunyu, A. (2017) Age and origin of the tsavorite and tanzanite mineralizing fluids in the Neoproterozoic Mozambique Metamorphic Belt. Canadian Mineralogist 55, 763-786.

Frisch, W. \& PoHL, W. (1986) Petrochemistry of some Mafic and Ultramafic Rocks from the Mozambique Belt, SEKenya. Wien. Mitteilungen der Österreichischen Geologischen Gesellschaft 78, 97-114.

Fritz, H., Tenczer, V., Hauzenberger, C., Wallbrecher, E., \& Muhongo, S. (2009) Hot granulite nappes - Tectonic styles and thermal evolution of the Proterozoic granulite belts in East Africa. Tectonophysics 477, 160-173.

Fritz, H., Abdelsalam, M., Ali, K.A., Bingen, B., Collins, A.S., Fowler, A.R., Ghebread, W., Hauzenberger, C.A., Johnson, P.R., Kusky, T.M., Macey, P., Muhongo, S., Stern, R.J., \& Viola, G. (2013) Orogen styles in the East Africa region: a review of the Neoproterozoic to Cambrian tectonic evolution. Journal of African Earth Sciences 86, 65-106.

Giuliani, G., Feneyrol, J., Ohnenstetter, D., Marshall, D., Walton, L., Martelat, J.-E., \& Fallick, A.E. (2014) Tsavorite and tanzanite deposits. In Geology of Gem Deposits (L. Groat, ed.). Mineralogical Association of Canada, Short Course Series 44, 217-246.

Harris, C., Hlongwane, W., Gule, N., \& Scheepers, R. (2014) Origin of tanzanite and associated gemstone mineralization at Merelani, Tanzania. South African Journal of Geology 117, 15-30.

Harrison, T.M., Celerier, J., Aikman, A.B., Hermann, J., \& Matthew, T. (2009) Diffusion of ${ }^{40} \mathrm{Ar}$ in muscovite. Geochimica et Cosmochimica Acta 73, 1039-1051.

Hauzenberger, C.A., Bauernhofer, A.H., Hoinkes, G., Wallbrecher, E., \& Mathu, E.M. (2004) Pan-African high pressure granulites from SE-Kenya: Petrological and geothermobarometric evidence for a polycyclic evolution 
in the Mozambique belt. Journal of African Earth Sciences 40, 245-268.

Hauzenberger, C.A., Robl, J., \& Stüwe, K. (2005) Garnet zoning in high pressure granulite-facies metapelites, Mozambique belt, SE-Kenya: constraints on the cooling history. European Journal of Mineralogy 17, 43-55.

Hauzenberger, C.A., Sommer, H., Fritz, H., Bauernhofer, A., Kröner, A., Hoinkes, G., Wallbrecher, E., \& Thöni, M. (2007) SHRIMP U-Pb zircon and Sm-Nd garnet ages from the granulite-facies basement of SE Kenya: evidence for Neoproterozoic polycyclic assembly of the Mozambique Belt. Journal of the Geological Society 164, 189-201.

Horkel, A., Nauta, W.J., Niedermayr, G., Okelo, R.E., Pohl, W., \& WachiRA, J.K. (1979) Geology of the Taita Hills. Report 102, Geological Survey of Kenya, Nairobi, 33 pp.

Hurai, V., Paquette, J.-L., Huraiová, M., \& KonečnÝ, P. (2010) Age of deep crustal magmatic chambers in the intra-Carpathian back-arc basin inferred from LA-ICPMS $\mathrm{U}-\mathrm{Th}-\mathrm{Pb}$ dating of zircon and monazite from igneous xenoliths in alkali basalts. Journal of Volcanology and Geothermal Research 198, 275-287.

Jackson, S.E., Pearson, N.J., Griffin, W.L., \& Belousova, E.A. (2004) The application of laser ablation-inductively coupled plasma-mass spectrometry to in situ $\mathrm{U}-\mathrm{Pb}$ zircon geochronology. Chemical Geology 211, 47-69.

Kriegsman, L.M. (1995) The Pan-African event in East Antarctica: a view from Sri Lanka and the Mozambique Belt. Precambrian Research 75, 263-277.

Le Goff, E., Deschamps, Y., \& Guerrot, C. (2010) Tectonic implications of new single zircon $\mathrm{Pb}-\mathrm{Pb}$ evaporation data in the Lossogonoi and Longido ruby-districts, Mozambican metamorphic Belt of north-eastern Tanzania. Comptes Rendus Geoscience 342, 36-45.

LuDwIG, K.R. (2001) Isoplot/Ex rev. 2.49- A Geochronological Toolkit for Microsoft Excel. Berkeley Geochronology center, Special publication, $\mathrm{N}^{\circ}$. 1a.

Malisa, E. \& Muhongo, S. (1990) Tectonic setting of gemstone mineralization in the Proterozoic metamorphic terrane of the Mozambique Belt in Tanzania. Precambrian Research 46, 167-176.

Martelat, J.-E., Giuliani, G., Ohnenstetter, D., Bosse, V., Paquette, J.-L., Omito, E., Ichang'i, D., Nyamai, Ch., \& WAMUNYU, A. (2015) U/Pb ages of zircon and monazite from the tsavorite-bearing Neoproterozoic rocks of southeastern Kenya, and the significance of static crystallisation of the tsavorite. Proceedings $13^{\text {th }}$ SGA biennal Meeting, August 24-27, 2015, Nancy, France, 4, 1311-1314.

Meert, J.G. (2003) A synopsis of events related to the assembly of eastern Gondwana. Tectonophysics 362, 1-40.

Meert, J.G., van der Voo, R., \& Ayub, S. (1995) Paleomagnetic investigation of the Neoproterozoic Gagwe lavas and Mbozi complex, Tanzania and the assembly of Gondwana. Precambrian Research 74, 225-244.

Mercier, A., Debat, P., \& Saul, J.M. (1999) Exotic origin of the ruby deposits of the Mangari area in SE Kenya. Ore Geology Reviews 14, 83-104.

Möller, A., Mezger, K., \& Schenk, V. (2000) U-Pb dating of metamorphic minerals: Pan-African metamorphism and prolonged slow cooling of high pressure granulites in Tanzania, East Africa. Precambrian Research 104, 123146 .

Müller, W., Shelley, M., Millerc, P., \& Broudec, S. (2009) Initial performance metrics of a new custom-designed ArF excimer LA-ICPMS system coupled to a two-volume laser-ablation cell. Journal of Analytical Atomic Spectrometry 24, 209-214.

OLIVIER, B. (2006) The geology and petrology of the Merelani tanzanite deposit, NE Tanzania. Ph.D., University of Stellenbosch, South Africa, 453 pp.

Paquette, J.-L. \& Pin, C. (2001) A new miniaturized extraction chromatography method for precise $\mathrm{U}-\mathrm{Pb}$ zircon geochronology. Chemical Geology 176, 311-319.

Paquette, J.-L. \& Tiepolo, M. (2007) High resolution (5 $\mu \mathrm{m})$ $\mathrm{U}-\mathrm{Th}-\mathrm{Pb}$ isotope dating of monazite with excimer laser ablation (ELA)-ICPMS. Chemical Geology 240, 222-237.

Paquette, J.-L., Nédélec, A., Moine, B., \& Rakotondrazafy, M. (1994) U-Pb, Single Zircon Pb-Evaporation, and Sm$\mathrm{Nd}$ Isotopic Study of a Granulite Domain in SE Madagascar. Journal of Geology 102, 523-538.

Paquette, J.-L., Piro, J., Devidal, J.-L., Bosse, V., \& Didier, A. (2014) Sensitivity Enhancement in LA-ICP-MS by N2 Addition to Carrier Gas: Application to Radiometric Dating of U-Th-Bearing Minerals. Agilent ICP-MS Journal 58, 4-5.

Pohl, W. \& Niedermayr, G. (1979) Geology of the Mwatate Quadrangle and the Vanadium Grossularite Deposits of the Area. Report 101, Geological Survey of Kenya, Nairobi, 55 pp.

Pohl, W., Horkel, A., Neubauer, W., Niedermayr, G., Okelo, R.E., Wachira, J.K., \& WernecK, W. (1980) Notes on the Geology and Mineral Resources of the Mtito Andei-Taita Area (Southern Kenya). Wien. Mitteilungen der Österreichischen Geologischen Gesellschaft 73, 135152 .

Quidelleur, X., Paquette, J.-L., Fiet, N., Takashima, R., Tiepolo, M., Desmares, D., Nishi, H., \& Grosheny, D. (2011) New U-Pb (ID-TIMS and LA-ICPMS) and ${ }^{40} \mathrm{Ar} /{ }^{39} \mathrm{Ar}$ geochronological constraints of the Cretaceous geologic time scale calibration from Hokkaido (Japan). Chemical Geology 286, 72-83.

SAGgerson, E.P. (1962) Geology of the Kasigau-Kurase Area. Report 51 (1958), Geological Survey of Kenya, Nairobi, $60 \mathrm{pp}$. 
SAnders, L.D. (1963) Geology of the Voi-South Yatta Area. Report 54 (1958), Geological Survey of Kenya, Nairobi, 48 pp.

Shackleton, R.M. (1996) The final collision zone between East and West Gondwana: where is it? Journal of African Earth Science 23, 271-287.

Simonet, C. (2000) Géologie des gisements de saphir et de rubis-L'exemple de la John Saul Ruby Mine, Mangare, Kenya. Ph.D. thesis, University of Nantes, France, 349 pp.

Simonet, C., OKundi, S., \& Masai, P., (2000) General setting of colored gemstone deposits in the Mozambique Belt of Kenya - preliminary considerations. Proceedings of the $9^{\text {th }}$ Conference of the Geological Society of Kenya, Nairobi, November, 123-138.

Simonet, C., Paquette, J.-L., Pin, C., Lasnier, B., \& Fritsch, E. (2004) The Dusi (Garba Tula) sapphire deposit, Central Kenya - a unique Panafrican corundum-bearing monzonite. Journal of African Earth Sciences 38, 401-410.

Sorokina, E.S., Rösel, D., Häger, T., Mertz-Kraus, R., \& SAUL, J.M. (2017) LA-ICP-MS U-Pb dating of rutile inclusions within corundum (ruby and sapphire): new constraints on the formation of corundum deposits along the Mozambique belt. Mineralium Deposita 52, 641-649.

STERn, R.J. (1994) Arc assembly and continental collision in the Neoproterozoic East African Orogen: implications for the consolidation of Gondwanaland. Annual Review of Earth \& Planetary Sciences 22, 319-351.

Suwa, K., Suzuki, K., \& Agata, T. (1996) Vanadium grossular from the Mozambique metamorphic rocks, south Kenya. Journal of Asian Earth Science 14, 299 308 .

Tenczer, V., Hauzenberger, C., Fritz, H., Hoinkes, G., Muhongo, S., \& KLÖtzli, U. (2013) Crustal age domains and metamorphic reworking of the deep crust in NorthernCentral Tanzania: a U/Pb zircon and monazite age study. Mineralogy and Petrology 107, 679-707.

Tera, F. \& Wasserburg, G.J. (1972) U-Th-Pb systematics in three Apollo 14 basalts and the problem of initial $\mathrm{Pb}$ in lunar rocks. Earth and Planetary Science Letters 14, 281304.

van Achterberg, E., Ryan, C.G., Jackson, S.E., \& Griffin, W. (2001) Data reduction software for LA-ICP-MS. In Laser ablation-ICPMS in the Earth Sciences: Principles and Applications (P. Sylvester, ed.). Mineralogical Association of Canada 29, 239-243.

Wamunyu, A., Ichang'i D, Giuliani, G., Martelat, J.-E., \& Оміто, E. (2015) Genesis of tsavorite deposits in the Davis mine, Mwatate, Southeastern Kenya. Proceedings $13^{\text {th }}$ SGA biennal Meeting, 24-27 August 2015, Nancy, France 4, 1339-1342.

Wiedenbeck, M., Allé, P., Corfu, F., Griffin, W.L., Meier, M., Oberli, F., \& Spiegel, W. (1995) Three natural zircon standards for U-Th- $\mathrm{Pb}$, Lu-Hf, trace element and REE analyses. Geostandards Newsletter 19, 1-23. 